\title{
13.6 Impacts of Mining on Geomorphic Systems
}

J Mossa, University of Florida, Gainesville, FL, USA

LA James, University of South Carolina, Columbia, SC, USA

(C) 2013 Elsevier Inc. All rights reserved.

13.6.1

13.6.2

13.6.2.1

13.6.2.1.1

13.6.2.1.2

13.6.2.2

13.6.3

13.6.3.1

13.6.3.2

13.6.3.2.1

13.6.3.2.2

13.6.3.3

13.6.3.3.1

13.6.3.3.2

13.6.3.3.3

13.6.3.3.4

13.6.3.3.5

13.6.4

13.6.4.1

13.6.4.1.1

13.6.4.1.2

13.6.4.2

13.6.4.2.1

13.6.4.2.2

13.6.5

13.6.6

References

\begin{tabular}{lr} 
Introduction & 75 \\
Types of Mines and Mining History & 76 \\
Types of Mining and Associated Landforms & 76 \\
Materials mined & 76 \\
Types of mining by nature of excavation & 77 \\
History of Mining & 81 \\
The Current Scenario & 84 \\
Mineral Consumption and Comparison with Other Geomorphic Processes & 84 \\
Mining Landscapes and Landscape Change & 85 \\
Comparisons of landscapes, waste rock, and geography & 85 \\
Open pits & 85 \\
Coal-Mining Landscapes & 85 \\
Phosphate-mining landscapes & 86 \\
Oil extraction landscapes & 86 \\
Sand and gravel-mining landscapes: Rivers and floodplains & 87 \\
Sand and gravel-mining landscapes: Coasts and lakes & 88 \\
Sand and gravel-mining landscapes: Glacial deposits & 89 \\
Mining and Geomorphic Hazards & 89 \\
Above-Ground Hazards & 89 \\
Mining and hillslope failures & 89 \\
Mine tailings and tailings dams failures & 89 \\
Below-Ground Hazards & 90 \\
Underground mining and subsidence & 90 \\
Catastrophic floods in underground mines & 90 \\
Geomorphology and Mine Reclamation & 91 \\
Conclusion & 92 \\
& 92 \\
\hline
\end{tabular}

\section{Glossary}

Adits A horizontal entrance to an underground mine that allows for drainage and ventilation.

Gangue The waste or commercially worthless material that is closely mixed with a wanted mineral in an ore deposit. Ground sluicing The use of flowing water to remove overburden and to expose and wash ore.

Ingot A usually metallic material that is castor molded into a shape suitable for further processing.

Nonentry mining A type of mining that is conducted from the surface and does not require underground deployment of personnel or heavy equipment.

Pozzolan An often siliceous material that is combined with calcium hydroxide and added to cement or concrete mixtures to increase the long-term strength and other material properties and in some cases to reduce the material cost of concrete rare earths.

Slag A partially vitreous or glass-like byproduct of smelting ore created when separating the metallic portion from the nonmetallic portion of rock.

Smelting A form of extractive metallurgy or the process that produces metal from ore.

Solution mining A mining process used to recover minerals through drilling boreholes into a deposit. Explosives or hydraulic fracturing may be used to create pathways in which a leaching solution is sent to dissolve ores. The solution is then pumped to the surface and processed.

Stope The open space created by the removal of the wanted ore from an underground mine.

Mossa, J., James, L.A., 2013. Impacts of mining on geomorphic systems. In Shroder, J. (Editor in chief), James, L.A., Harden, C.P., Clague, J.J. (Eds.), Treatise on Geomorphology. Academic Press, San Diego, CA, vol. 13, Geomorphology of Human Disturbances, Climate Change, and Natural Hazards, pp. 74-95. 
Tailings Materials left over after the process of separating the valuable fraction from the uneconomic fraction of an ore.
Waste rock The materials overlying an ore or mineral body that are displaced during mining without being processed.

\begin{abstract}
Mining is an activity integral to modern society that has a long history and occurs in a wide range of geomorphic settings. It is of interest to geomorphologists because of the unique types of excavated and accumulated landforms and landscapes that are vulnerable to geomorphic hazards. Mining landscapes covered more than a half million hectares worldwide in 1990 (Young, 1992), and are responsible for more sediment production than paved road construction, house construction, and agriculture, which, in combination, produce more sediment than natural processes (Hooke, 1994). Mining-related removal of vegetation and surface sediments, blasting, creation of stock piles and gangue, and increasing slopes make landscapes more vulnerable to failures, erosion, floods, subsidence, and other geomorphic hazards and have been the subject of a number of studies. Effective application of geomorphology is an important tool in preventing or minimizing the negative effects of mining. This chapter discusses the types of mining operations, the history of mining, and some current geomorphic topics in mining, which include landforms and landscapes, geomorphic impacts and hazards, and the nascent field of mined land reclamation. We have much still to learn from the study of mining landscapes, with potential applications in landscape evolution, models of geomorphic hazards, reclamation, and Quaternary geology and geomorphology. Given a growing global population, and expanding demands for mineral resources, the need for sustainable practices will increase and wise application of geomorphic knowledge in mined landscapes will become increasingly important.
\end{abstract}

\subsubsection{Introduction}

Mining, the extraction of geological materials from the Earth is inextricably tied to geomorphology. Geomorphic processes, such as weathering, sorting by water and wind, sedimentation, and subsurface processes involving water and magmas, form or influence the locations of mineral deposits. Activities associated with extracting substances from near the surface of the Earth and dealing with the overburden and waste rock create unique excavated (negative), accumulated (positive), and planed landforms and landscapes (Dávid, 2010). Removal of vegetation and surface sediments and activities, such as blasting, dumping unused materials, and increasing slopes, make mined landscapes vulnerable to failures, erosion, floods, subsidence, and other geomorphic hazards. Studies of mining landscapes have contributed to geomorphic knowledge of landscape evolution (Haigh, 1978) and better understanding of hazardous landscapes of waste tips (Sütö, 2010). Examination of exposures in quarries and sand and gravel pits has informed Quaternary geology and geomorphology. In turn, using geomorphic data, principles, and understanding improves reclamation following mineral extraction and results in landscapes that function better and are less susceptible to hazards.

Mining has been undertaken for a wide variety of purposes, including obtaining materials for making items such as tools, utensils, weapons, ornaments, decoration, currency, structures, and machinery, and obtaining resources for energy, electronics, and nuclear fission (Hartmann and Mutmansky, 2002). The quarrying of flint stones is a rudimentary form of mining; thus, the history of mining precedes the Neolithic and is a subject of interest for archeologists. Quarries in Hungary, for instance, data back 100-120 ka (Dávid, 2010). Classification of prehistoric cultural periods as the Stone, Bronze, and Iron Ages, especially in Europe, the Mediterranean, and Near
East, emphasizes the ability of early societies to use materials acquired through mining. The search for precious metals and gems today, especially in developing countries, is partly artisanal in character. Human labor and simple tools are all that are needed to extract minerals from rivers, quarries, and elsewhere in a variety of locales throughout the world.

Industrialization increased the demand for fossil fuels and the importance of mining. Modern technology, such as hydraulic dredges, bulldozers, excavators, draglines, and explosives, greatly accelerates the rate of extraction. These technologies are used to remove overburden, scrape surfaces, and create above-ground pits or dig below-ground tunnels, depending upon the commodity, its position within the Earth, and local factors such as topography and geology. Roads and pipelines, built to transport minerals for processing, create additional resource demands and varied impacts. With some types of mining, under regulated conditions, measures may be taken to retain materials on site by building settling ponds, earthen dams, and levees, or clay liners, thereby requiring the use of even more products from the Earth. Through the processes of searching for, sorting through, or extracting earth materials, existing landscapes are altered and waste rock is produced. A variety of new features may be created, including planed mountaintops, sculpted mountainsides, canals and ponds, alluvial fans and terraces, debris aprons, conical mounds, towering piles, deep pits with benched walls and floors, underground tunnels, and wide, shallow depressions.

Landscapes created by mining are susceptible to a variety of geomorphic hazards. It is widely known that steep, unvegetated slopes are susceptible to mass wasting processes, such as landslides and rockfalls. Flooded mines are a potential hazard, as water can enter pits and tunnels from above. Increased flooding along rivers and streams may occur from a variety of processes; waste rock dumping in river valleys reduces channel capacity, channel instability may result in 
downstream sedimentation and flooding, and mine dam failures can result in catastrophic floods. Underground mining may result in catastrophic local collapse or longer-term subsidence over broad areas. Less obvious are the impacts attributed to petroleum extraction wells; in some locations, associated access canals cause direct losses of wetlands and indirect coastal land losses by making the landscape more vulnerable to damage from storms. Geomorphic processes may be accelerated by mining disturbances; the rate of channel change, as measured by lateral migration, alluvial bar size, avulsions, or bed changes such as aggradation and degradation are commonly a significant problem in locations with floodplain sand and gravel mining. Off-site impacts are also common, particularly in mining of metals, as many earthen dams designed to facilitate mineral processing have failed, resulting in mine tailings spills.

The purpose of this chapter is to provide an overview of some of the impacts of mining on geomorphic systems. First, we begin with a general background of the history and types of mining. Mining is defined and then classified by the materials mined and nature of excavation. A brief summary of the long history of mining is presented. Then, the current and recent past situation is discussed, examining the landscapes and landscape changes associated with mining or extraction of different materials. Using examples worldwide, some catastrophic events and geomorphic hazards at mining sites, above ground and below ground, on site and off site, are reviewed. Finally, a brief discussion is presented of reclamation to improve the potential environmental utility, quality, and appearance, and to reduce hazards for landscapes that have been modified by mineral extraction.

\subsubsection{Types of Mines and Mining History}

\subsubsection{Types of Mining and Associated Landforms}

'Mining' is generally defined in the context of the operation of mines and, therefore, implies an excavation in the ground with tunnels, shafts, or pits. In common usage, 'mining' also refers to open-pit mining methods, especially where modified, such as open-cast mining or aggregate mining.

Mining. The science, technique, and business of mineral discovery and exploitation. Strictly, the word connotes underground work directed to severance and treatment of ore or associated rock. Practically, it includes open-cast work, quarrying, alluvial dredging, and combined operations, including surface and underground attack and ore treatment. (US Bureau of Mines 1996).

Nonentry methods of extraction, such as wells and solution mining, may or may not be considered forms of mining, but this chapter takes a broad view to include all mineral extraction by surface or underground excavations and the geomorphic impacts of these activities.

\subsection{Materials mined}

Mines and mining can be classified in many ways. One distinction is based on the economic minerals extracted, as this generally imposes constraints on the mining technologies and their geomorphic impacts. For example, placer mining or sand and gravel mining commonly involves surface mining with scrapers, pits, or dredging, whereas diamond and quartz-gold mines characteristically require deep underground mining processes. Gemstones and some precious metals may be mined by artisans using relatively simple and inexpensive surface or near-surface technologies. Based on materials mined, three classes of mining can be identified: metallic, nonmetallic, and fuel minerals (Table 1). The target of mining is an ore, that is, a mineral with economic value. 'Ore' may refer to the rock material that contains valuable materials, and definitions commonly specify that the deposit must be capable of being profitably mined to classify as an ore. Thus, classification of a rock body as an ore may change through time with changes in market conditions and technology and cost of extraction and transport of commodities.

Mining for metals generally involves crushing and grinding ore to separate and concentrate metals from gangue, that is, low-grade waste material. The high-grade ore may then be smelted to further concentrate and purify metals into ingots, leaving behind a slag of low-quality metal that may be marketed or discarded on site. Most separation and, with the possible exception of precious metals, most smelting are done near the mine to reduce transportation costs. Thus, tailings of waste materials of low-grade ore and slag are commonly located near mines.

Nonmetallic mineral mining includes the excavation of aggregate (sand and gravel) and salts, including halite $(\mathrm{NaCl})$, gypsum $\left(\mathrm{CaSO}_{4} \cdot 2 \mathrm{H}_{2} \mathrm{O}\right)$, anhydrite $\left(\mathrm{CaSO}_{4}\right)$, potassium, phosphates, and other minerals. Fuel minerals are mined extensively, especially anthracite, bituminous coal, lignite, and peat. Knowledge of geomorphology or structural geology can greatly improve the ability to locate specific types of mineral deposits. Cooke and Doornkamp (1990) presented an extensive matrix derived from Demek (1972) that illustrated these relationships.

Table 1 Materials commonly mined

Metaliferous materials

Precious metals - gold, silver, platinum, etc.

Industrial and heavy metals - copper, lead, zinc, tin, iron, molybdenum, tungsten, vanadium, aluminum, uranium, zirconium titanium, etc.

Nonmetallic minerals and materials

Insulation - mica, asbestos

Refractory - silica, graphite, zircon

Gems and abrasives - diamond, sapphire, corundum, garnet, topaz, emerald

Industrial minerals - barite, limestone, halite, anhydrite, gypsum, clay, sulfur

Construction materials - sand and gravel, crushed stone, dimension stone

Agricultural minerals - phosphate, potassium

Fuel minerals

Solids - coal, anthracite, lignite, oil shale

Fluids - petroleum and natural gas (technically, drilling for these fuels is not mining)

Source: Adapted with permission from Gregory, C.E., 1980. A Concise History of Mining. Pergamon Press, New York; Oxford, 259 pp. 
Specifying the material mined does not always provide sufficient information to allow inference of the mode of mining. For example, salt mining may be performed by a variety of methods, including surface extractions and underground tunneling, or by solution methods that pump water through an underground deposit and recover a salt solution. Thus, to better understand mining landscapes, some discussion of the nature and variety of excavations is relevant, as is discussion of how technology is applied to mining and how this has evolved through history.

\subsection{Types of mining by nature of excavation}

The type of excavation generated by mining has great bearing on the geomorphic and environmental impacts. Most types of mineral extraction can be separated into two classes: surface and underground mining, although combinations of the two may occur in time and space (Table 2). For example, tailings piles from an underground mine may be reworked by surface mining methods, and deep placer deposits may be excavated by tunneling. Nonentry excavation methods are included in Table 2 for the sake of comprehensive treatment. Although they are not actual forms of mining, some of these methods, for example, augering, are commonly used in conjunction with surface or underground mines.

Underground mining is used for deep mineral extraction and includes the excavation of vertical deposits such as metalliferous ores and horizontally bedded deposits, especially coal. Deep underground mines require tunneling and drilling that may change water tables, cause subsidence, generate tailings and dust, and introduce chemical changes to the groundwater that then get into streams, soils, and biological systems. This form of mining is expensive and is generally relegated to valuable minerals such as metals. With the exception of coal, underground mining tends to remove less material than surface mining, owing to the expense of removal and the tendency to replace waste materials underground by various 'stoping' methods.
Geomorphic effects of underground mining vary greatly with the amounts and types of materials worked. Given the high price of removal, much low-grade rock may be left underground by various stope-and-fill methods by which rock is moved and relocated within the mine in vertical, horizontal, or inclined steps. Since the density of waste material is substantially less than the density of the original rock, volumes of waste material may completely fill the tunnels and shafts of abandoned areas of the mine even after substantial amounts of ore is removed. However, this filling does not preclude postmine impacts such as subsidence and groundwater percolation.

Surface mining includes open-pit mining (also known as open-cut or open-cast mining), strip mining of shallow, horizontally oriented materials, alluvial mining for heavy minerals in sorted sediment, and quarrying of construction stone. These methods are used for shallow materials where costs of removing an overburden are not prohibitive. As the depth of the ore increases, the volume of surface material that must be removed increases geometrically. At some critical thickness of overburden, underground mining techniques may become more economic to use than surface methods, depending on the value, thickness, and concentration of the minerals and costs of operation. For shallow deposits, surface excavations have the potential to remove vast quantities of material. These methods are used extensively to excavate coal, evaporites on lake beds, and aggregate for construction materials. Surface mining has obvious direct impacts on geomorphic features and may create large landforms by excavation (Figure 1) and the addition of mine tailings. Surface mining accounts for the greatest masses or volumes of total material excavated, so it is a primary focus of this chapter.

Open-pit mining is used to extract deep, massive deposits that do not have a thick overburden. For such deposits, underground mining would be more expensive because much of the material is near the surface, and none of the deposit would be sufficiently deep to preclude surface

Table 2 Types of mining. Gregory's separate class of alluvial mining is here combined with surface mining

\begin{tabular}{ll}
\hline Underground mining & Deep excavations of vertical ore bodies with shafts,tunnels, adits, etc. \\
Surface mining & Excavation of surface or shallow materials \\
Open-pit (open-cut) mining & Vertically extensive ores \\
Strip mining & Horizontally bedded ores, materials, coal, aggregate, lakeevaporates, draglines, power shovels, bucket \\
& ladders, front-end loaders, etc. \\
Alluvial (placer) mining & Removal of heavy (dense) minerals from sorted sediment \\
& Stream beds, beach dunes, ocean dredging (e.g.,manganese nodules) \\
Hydraulic mining & Use of pressurized water to move sediment \\
Quarrying stone & Construction materials \\
Nonentry extractions & Technically, nonentry methods are not 'mining' \\
Wells & Drilling for fluids (oil, gas) \\
Augering & Drilling for solids (e.g., coal) \\
Gasification & Underground conversion to gas (e.g., coal) \\
Solution mining & Solutions are injected to dissolve ore; solutes retrieved. Water solutions for salt; copper or uranium with \\
chemical solutions; Frasch method for sulfur (superheated water) \\
Hydraulic Fracturing (fracking) & Generation of rock fractures to increase hydraulic conductivities and release trapped fluids. Typically used to \\
& extract oil or natural gas from wells. \\
\hline
\end{tabular}

Source: Adapted with permission from Gregory, C.E., 1980. A Concise History of Mining. Pergamon Press, New York; Oxford, 259 pp. 


\section{Author's personal copy}
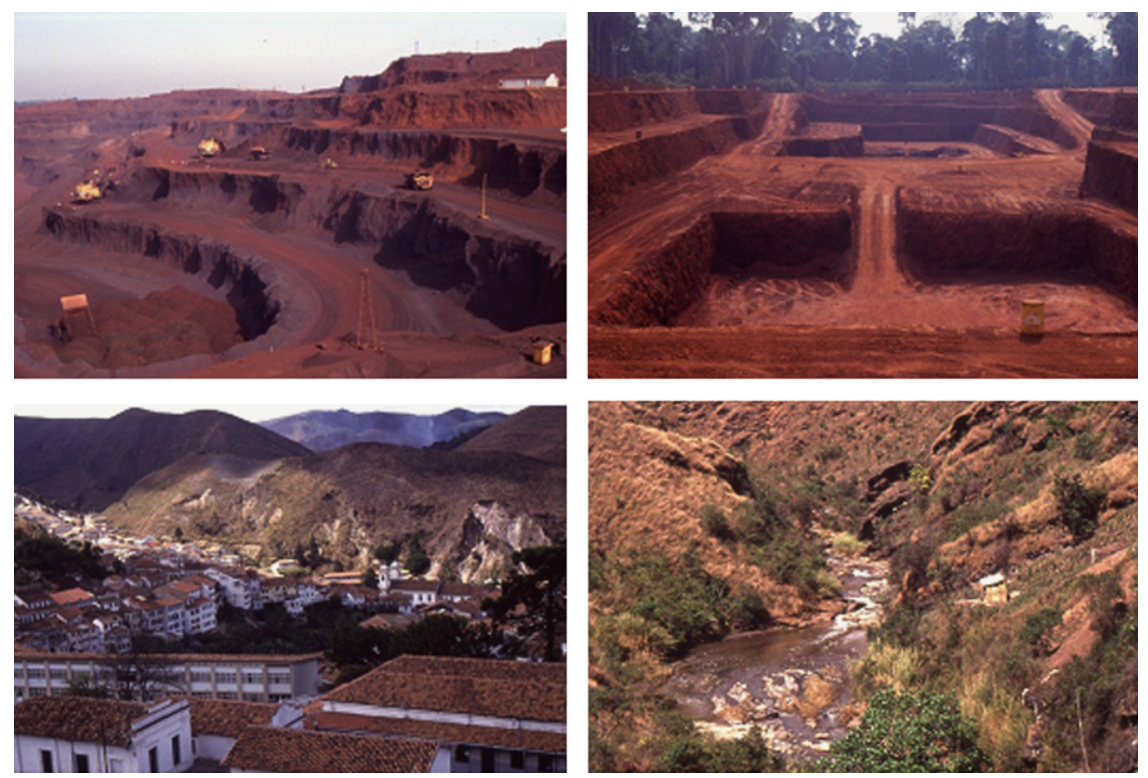

Figure 1 Landscapes of mineral extraction, Brazil, contrasting landforms of industrial open-pit mining with artisanal mining. Top: Left photo shows benches in one of the world's largest iron ore mines, Carajás, which contains about 18 billion tons of iron ore, plus gold, manganese, copper, and nickel. Right photo shows unique landforms in the Carajás open-pit mine; Lower: Left photo shows how artisanal gemstone mining in the hills surrounding Ouro Preto leaves scars on the landscape; right photo shows how artisanal placer mining in a stream near Ouro Preto alters the bar forms by dividing one large bar into slivers (photo credits: J. Mossa).

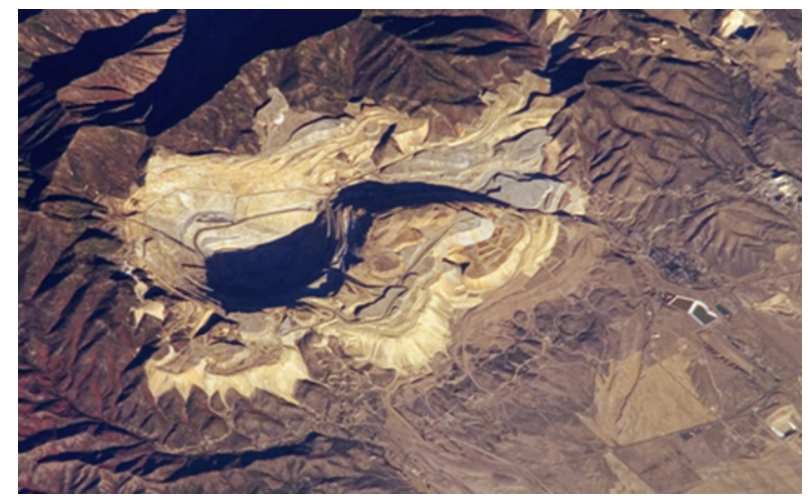

Figure 2 Bingham Mine. Bingham Canyon Mine, in the Oquirrh Mountains, Utah. Width of image extends approximately $14.5 \mathrm{~km}$. Photograph taken by NASA astronaut, September 20, 2007. Image provided by NASA Earth Observatory, ISS Crew Earth Observations experiment, and the Image Science and Analysis Laboratory, Johnson Space Center. http://earthobservatory.nasa.gov//0TD/view.php?id=8144

methods. Costs of underground mining have increased more than costs of surface mining on a per unit lode basis, so openpit mining has been extended to far greater depths than had been attempted in the past. For example, the Bingham copper mine in Utah, USA, has been continuously mined and enlarged since 1863 and is now one of the greatest anthropogenic excavations on Earth (Figure 2).

Coal mining is a form of surface mining that may cause extreme geomorphic changes and may involve any of several mining techniques. In Appalachia, three types of surface mining are common: contour, auger-highwall, and area mining. Various combinations of these methods are commonly referred to as mountaintop mining (GAO, 2009). Contour

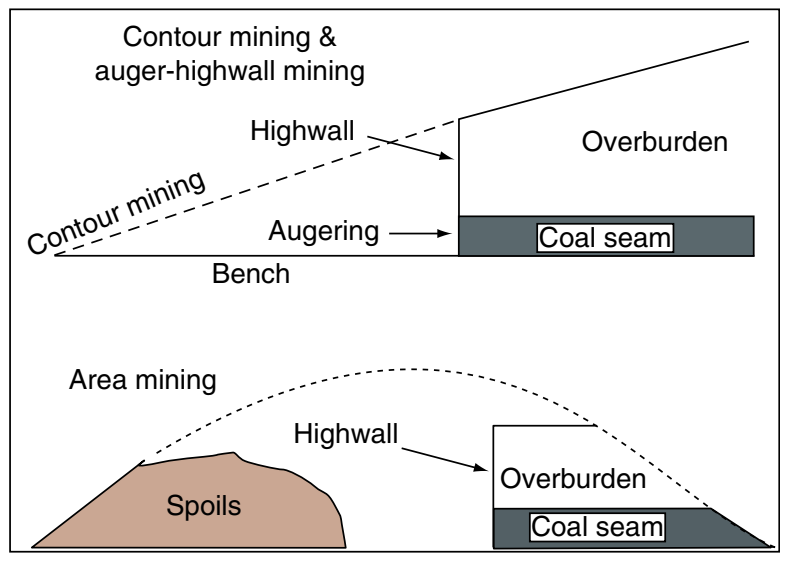

Figure 3 Three types of mountaintop coal mining. Adapted from Government Accounting Office (GA0), 2009. Surface Coal Mining: Characteristics of Mining in Mountainous Areas of Kentucky and West Virginia, GA0-10-21. Washington, DC.

mining exploits flat-lying strata exposed on hillslopes by removing a band of overburden to expose the coal seam. The mine extends back into the slope until the overburden is too thick for economic removal. At this point, the mine face has become a highwall, and removal of additional coal may be done by augering or tunneling horizontally into the seam (Figure 3). In locations where contour and auger-highwall minings cannot extract coal economically, large portions of the mountaintop can be removed by area mining. This method generally begins with a cut parallel to the ridge crest to remove the overburden, create a bench to work from, and expose the seam at depth. In all of these forms of coal mining, large volumes of spoils are generated that must be 
disposed of. This is commonly done by returning spoils to worked-out areas of the mine or trucking them to nearby valleys.

Mining sediment from water bodies and low-lying sites, such as floodplains, rivers, harbors, estuaries, and other lowlying areas, is common not only for the commercial value of the materials (i.e., mining) but also to improve navigability, reduce flood hazards, build artificial levees or embankments, and restore aquatic systems. These forms of extraction include in-stream mining and other aggregate mines in lowland areas. Aggregate is the world's number-one nonfuel mineral commodity in terms of both volume and value. During 1998, worldwide, about 20 billion tons of aggregate worth about 120 billion Euros were produced (Wellmer and Becker-Platen, 2002), and aggregate production accounts for about half of the nonfuel-mining volume in the United States (Langer et al., 2004). In-stream mining is particularly disruptive to aquatic habitats, but its impacts may extend well beyond the stream bed to wetlands that may be damaged by lowered water tables, bank erosion, channel relocation, or dumping of waste materials (Femmer, 2002).

Aggregate mining from rivers falls into two categories. Mining in active channels that are frequently inundated usually involves shallow excavations that may be replenished during high water flows, but may cause river-channel changes that can propagate downstream over great distances (Harvey and Schumm, 1987; Kondolf, 1994; 1997; Gaillot and Piégay, 1999; Surian et al., 2009). Environmental issues and regulatory procedures related to in-stream mining in the United States were reviewed by Meador and Layher (1998). Mining floodplains and inactive channels, such as terrace deposits or paleochannel systems, may involve large, deep permanent pits, where close to the channel, streams can avulse into these pits, causing planform change as well as the profile changes, such as deep spots in the channel bed and subsequent knickpoint migration, characteristic of in-stream mining (Norman et al. 1998; Mossa and Marks, 2011).

In-stream mining may be executed by bulldozers, front-end loaders, scrapers, draglines, or dredges (Figure 4). Dredging usually exploits sediment in shallow water. It may be used to keep waterways clear or for the acquisition of aggregate, metaliferous placer deposits, or other commercial commodities. The two primary types of dredges are mechanical and hydraulic (suction), which involve scraping and sucking of bottom sediments, respectively (Herbich, 1981). Mechanical dredges, including dipper, grapple (aka grab), and
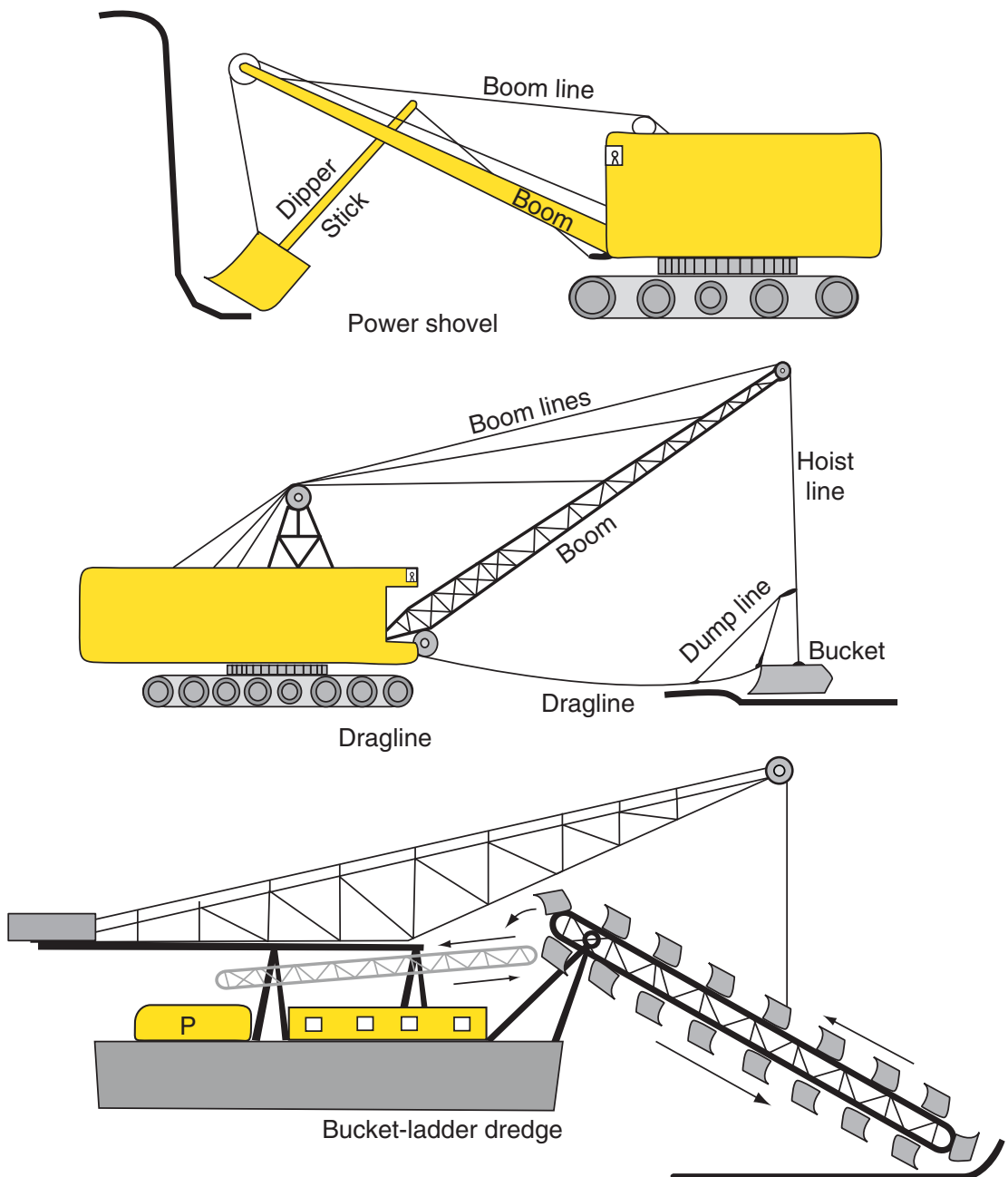

Figure 4 Surface mining excavators. Adapted from Gregory, C.E., 1980. A Concise History of Mining. Pergamon Press, New York, Oxford, 259 pp. 
bucket-ladder dredges, have limited mobilities and capacities and produce material near the dredge site. A dipper dredge (backhoe dredge) utilizes a large, barge-mounted excavating shovel and can be used with relatively coarse sediment. Grapple dredges, which are best used in relatively soft sediment, have a derrick mounted on a barge supporting a clamshell bucket. Bucket-ladder dredges use a revolving chain of buckets so that each bucket descends over the bow, scrapes the bottom, and is raised full of sediment to the rear of the chain. Bucket-ladder dredges achieve continuous excavation and are the most rapid means of excavation for a given bucket capacity. The elevated payload can be linked to conveyor belts for transport and screening apparatuses to generate graded construction materials.

Hydraulic dredges, including dustpan, cutter head, and trailing suction hopper dredges, are the best method for dredging in deep, open water (Herbich, 1981). Material is typically disaggregated with cutters or jets, mixed with water, and removed in a slurry through a pipeline to barges or an offsite location. Dustpan hydraulic dredges have a broad horizontal suction intake with hydraulic jets that is lowered by wenches from the front of the vessel. Cutter-head hydraulic pipeline dredges use an agitator that moves horizontally in front of the suction head and may generate high turbidities in fine sediment. Either type of suction dredge may be used to dredge gravel or rock. Trailing suction hopper dredges use no pipeline, but store sediment on board, sail to the disposal site, and release it. Hydraulic dredges have variable impacts depending on their type and size and the nature of materials being worked.

Dredging can have dramatic geomorphic effects on channels, floodplains, harbors, inlets, and other subaqueous sites or locations adjacent to water bodies (Lagasse et al., 1980; Hay, 1985; Lagasse, 1986). The geomorphic effects of dredging include not only the removal of materials but also the construction of landforms, such as artificial dunes, or wider beaches with beach replenishment and stock or tailings piles. For example, the Yuba Gold Fields is an area in northern California where the entire valley bottom, including the floodplain and Quaternary terraces, was mechanically dredged for gold in the first half of the twentieth century (Figure 5). The resulting tailings form ridges of loose cobbles, gravel, and sand that exceed $20 \mathrm{~m}$ in height in some places and may produce bed material to the river during floods. The presence of high concentrations of mercury in some of these sediments compounds the environmental dangers of these sediment deliveries (Hunerlach et al., 2004).

The large-scale dredging described above should not be confused with small-scale suction dredging that is commonly used by artisanal placer-mining operations. Those operations tend to be local in extent and have less geomorphic impact. Yet, artisanal suction dredging can have severe impacts on local habitat (Griffith and Andrews, 1981; Somer and Hassler, 1992; Harvey and Lisle, 1998). Other equipment related to dredging include snagboats that are used to remove large woody debris from navigable waters.

Ground sluicing, also known as hushing or booming, is the use of flowing water to remove overburden and to expose and wash ore. Sluicing had been used for at least two millennia (May, 1970), and is described by Pliny the Elder (AD 77-79). In some cases, sluicing was practiced at such a
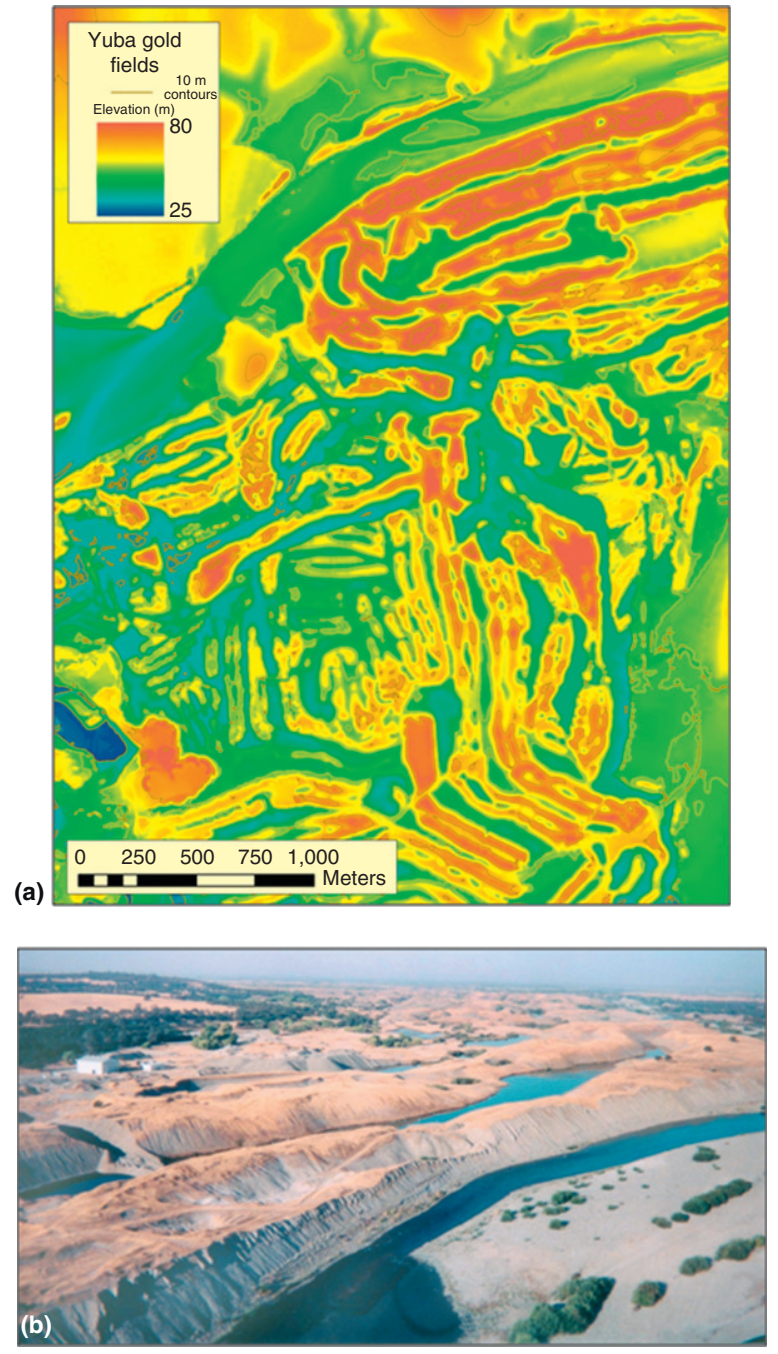

Figure 5 Yuba Gold Fields, CA. Area dredged extensively by mechanical dredges, especially bucket-ladder dredges, during the first half of twentieth century. (a) Typical ridge-and-swale topography left along-side floating barges. Shaded relief derived from 1999 LiDAR imagery. Reproduced from Stonestreet, S.E., Lee, A.S., 2000. Use of LIDAR mapping for floodplain studies. In: Hotchkiss, R.H., Glade, M.

(Eds.), Proceedings, Building Partnerships - 2000 Joint Conference on Water Resource Engineering, Planning, and Management: Minneapolis, Minnesota, American Society of Civil Engineers. doi: 10.1061/

40517(2000)58. (b) Oblique downstream view across Yuba River from helicopter, April 2007 (photo credit: L.A. James).

large scale that temporary reservoirs were constructed to store large volumes of water for sudden release to sluice away overburdens. The geomorphic impacts of large-scale sluicing in Wales are revealed by former reservoir sites and gullying below (Hughes, 1994). Hydraulic mining is the application of pressurized water through hoses and nozzles. The delivery of water from an elevated position, use of enclosed pipes or hoses to build pressure, and use of nozzles or water cannons distinguish hydraulic mining from ground sluicing (May, 1970). Hydraulic mining has the potential to do tremendous amounts of geomorphic work and is illegal in most populated areas of developed nations. 
Artisanal mining and small-scale mining are used synonymously here to refer to mining performed by individuals or small groups with a limited amount of technology or machinery. Disturbance in these landscapes includes bare hillslopes susceptible to failure and altered bar forms (Figure 1). This form of mining is labor intensive and may occur in remote areas. The earliest mines were artisanal and the ongoing search for precious metals and gems, especially in developing countries, is largely by artisanal mining. Many small-scale mines utilize practices that are poorly monitored and may involve the use of chemicals such as cyanide or mercury. On an individual basis, these activities are not likely to have a substantial geomorphic effect, but the cumulative impact on geomorphic systems may be substantial if a large number of operations are involved over a period of time. When a rich concentration of a valuable mineral resource is initially discovered, a great number of prospectors and miners with varying levels of experience may converge in what may be referred to as a 'rush' or 'boom'. These events may have direct and indirect geomorphic impacts on an area through the combined effects of thousands of artisanal miners, and - if the mineral deposits prove to be viable - they may evolve into a protracted period of advanced mining activities as the intensity, organization, and capitalization of mining operations grow. Mineral rushes have occurred throughout history. For example, a gold rush ensued in Romania in the second century $\mathrm{AD}$ after tremendous amounts of gold were brought to Rome from Roman conquest (Gregory, 1980). Increased mobility, personal independence, and the emphasis on gold and other precious metals following the periods of conquest and colonial expansion led to a proliferation of rushes and booms, especially in the New World (Smith, 1987). The California gold rush of 1849 is an extreme and well-documented example of both human and environmental dimensions of a major mining boom (Paul, 1947; Holliday, 1981, 1999). Mining boom-and-bust cycles may have geomorphic influences that extend well beyond the direct environmental impacts. Exploitation of water and timber for fuel, construction of canals, and timbering shafts and adits may have substantial influences on local erosion and sedimentation rates. Thus, evidence of episodic increases in geomorphic activity caused by mining may be recorded in alluvial records.

Nonentry extractions include wells, augering, gasification, solution mining, and fracking (Table 2). In oil and gas drilling, hydraulic fracturing (fracking), the creation of rock fractures, is increasingly common. Injecting a fracturing fluid into wells under pressure dilates rocks, generates cracks, and increases the hydraulic conductivity of the rocks. By including particulate matter such as sand with the fracturing fluid, the expanded pore spaces tend to remain open when pressure is lowered. After fracking, the flow of trapped fluids towards the well head can be greatly improved.

\subsubsection{History of Mining}

Prior to mining, early hunter-gatherers collected stones and other resources from the surface. This inevitably led to digging shallow pits for valuable resources such as stone, pigments, coal, and salt. Simple pits ultimately evolved into tunnels and quarries and the materials mined expanded to include ceramics, metals, and other valuable commodities. At some point along this continuum, the earliest forms of mining evolved from the simple gathering of surface resources. In some locations, early societies dug caves in loess and volcanic ash for habitations. Although this was not generally for the purpose of resource extraction and may not be formally defined as mining, it was an anthropogenic geomorphic activity that is best grouped with mining activities. One of the earliest known mines, Bomru Ridge Mine in Swaziland, Africa, was exploiting hematite for its red dye properties (Gregory, 1980).

Early underground mining was characterized by limited depths and penetration and lack of exploratory drilling or tunneling. Shafts seldom exceeded $10 \mathrm{~m}$ and excavations generally terminated when ore bodies terminated at faults or other offsets or with groundwater, lack of ventilation, or other impediments (Craddock, 1995). Archeological evidence in Hungary indicates that flint mines were established more than $100000 \mathrm{a} \mathrm{BP}$, and many operated in the Neolithic 8000-10 000 a BP (Dávid, 2010). Neolithic extraction of secondary flints has been recorded in many locations across Europe. Secondary flint deposits are locations where flint can be reliably found in abundant quantities and is not in a primary geologic formation but is redeposited in old alluvium, coastal sediments, or other secondary deposits. The Neolithic mines tended to be shallow pits with processing done on site. Some mining probably began in late Mesolithic, but quarrying did not begin until a developed stage of the Neolithic (Saville, 2008). Neolithic quarrying was done with small approximately circular pits, $3-8 \mathrm{~m}$ in diameter and up to $4 \mathrm{~m}$ in depth. Limited ${ }^{14} \mathrm{C}$ dating suggests that some of the pits were excavated between c. 3000 and 3500 BCE (Saville, 2008).

Some mines have been repeatedly used since prehistory, including salt mines near Hallein, Austria, and Bad Reichenhall, Germany (Johnson and Lewis, 1995). Fire setting, that is, heating rock with fire and then dousing with water, to fracture rock for excavation, has been used for several millennia. Evidence of fire setting for extracting metals has been shown for the Bronze Age (Heiss and Oeggl, 2008). Sand and gravel extraction from rivers has a long history owing to the ready availability of well-sorted materials suitable for building roads and structures (Sear and Archer, 1998).

Mining was an important activity in Greek and Roman times, and a few historical descriptions of Roman mining have survived. Vitruvius (c.15 BCE), in de Architectura, described the contemporary machinery and materials used by the Romans for mining, such as surveying equipment, hoists, cranes, tread wheels for removing water, Archimedes screws, aqueducts, and concrete. Pliny the Elder (23-79 CE) documented mining practices at the time of the Roman Empire in his encyclopedic Naturalis Historia (Pliny, c. 77-79). Pliny's Natural History includes discourses on metallurgy, mineralogy, and Roman Mining. These early descriptions are primarily concerned with gold mining and may be based largely on mines in northern Spain, although similar Roman mining methods have been documented in the United Kingdom in Wales. Many Roman mining areas have been studied in detail by archeologists, and the evidence tends to support the descriptions of Pliny. The techniques described include the use of fire setting, use of adits for ventilation, delivery of water in aqueducts, and use of water by ground sluicing. Sluicing may have been vaguely 
referred to by Strabo (c. $25 \mathrm{BCE}$ ) prior to the clear description provided by Pliny the Elder. In the extreme, sluicing could involve the damming of surface water in tributaries and its rapid release to encourage a torrent of water below (Hughes, 1994).

Mining technology, metallurgy, and mineralogy had progressed to an advanced degree in Medieval Europe. The writings and illustrations by Georgius Agricola (1494-1555) document the scientific basis of geology and mining technology in the mid-sixteenth century. Agricola is commonly considered a father of geology as his observations and interpretations provided a foundation for Nicholas Steno and other great scientists to follow. His first major work was the Bermannus, sive de re metallica (Agricola, 1530), a geologic treatise on the mountains of Bohemia that border Germany and the Czech Republic. At the time of Agricola's writing, 'metal' was more broadly interpreted to include a wide range of ore minerals. Bermannus was reprinted in 1546, along with four new papers on geology, in a treatise commonly referred to as the 'First Handbook of Modern Systematic Mineralogy,' which included De Ortu et Causis Subterraneorum and De Natura Fossilium (Agricola, 1546). In 1556, Agricola published his most influential work, De re Metallica (on the nature of minerals; Agricola, 1556). This book not only examined the geologic context of mining but also provided a comprehensive treatise on mining technologies of the period based on Agricola's extensive experience in mining towns of Bohemia. This treatise includes detailed definitions, explanations, and instructions for prospecting, surveying, rock extraction, expelling gases, pumping groundwater, assaying ore, crushing and washing, smelting, and separating minerals. Agricola did not mention sluicing, but he illustrated the use of flumes and other uses of water in mining. The book was beautifully illustrated with a large number of woodcuts that focus on mining technology of the day (Figure 6). The first English translation of Metallica was produced in 1912 by Herbert Hoover, later to be
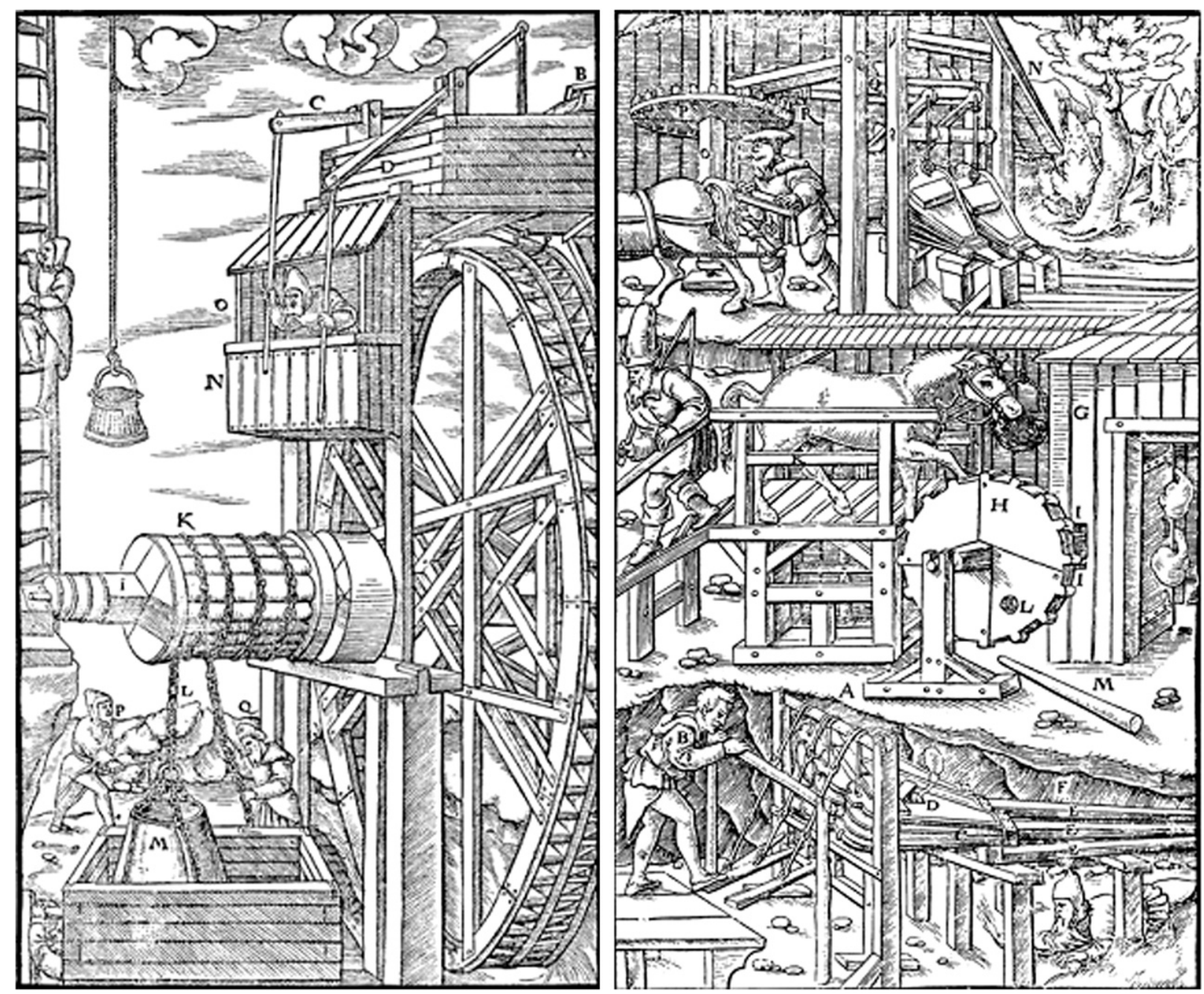

Figure 6 Two woodcuts by Agricola (1556). Left: A large windlass (K) powered by a reversible water wheel beginning to lower a load (M) into a mine shaft. When the load reaches the appropriate level in the mine, the operator $(0)$ can raise or lower levers $(C$ and $D)$ to change the flow from one set of buckets on the wheel to the other to reverse the direction of rotation and begin raising the load. Right: Three machines for operating bellows to ventilate a mine. The top example uses a horizontal horse-powered wheel to turn a shaft with cams to power two bellows blowing air from the surface into a ventilation shaft. The middle level uses a vertical horse-powered wheel $(H)$ to operate bellows hidden in the room behind $(G)$. In the bottom level, two foot pedals power the bank of three bellows (D) providing air to the shaft at right. 
elected the 31st President of the United States. The work of Agricola shows unequivocally that the science of mining was scientifically and technologically advanced in his time.

Hydraulic mining is a relatively modern development in mining history. The advent and rapid development of this technology in the mid-nineteenth century has been described in detail (Bowie, 1885; May, 1970; Holiday, 1999; Greenland, 2001). The first recorded use of hydraulic mining, that is, applying water through a hose fitted with a nozzle to develop pressure, was developed in the gold districts near Nevada City, CA, between 1852 and 1853. Conditions in these mining districts were ideal for hydraulic mining, with rich placer deposits on high ridges where water could be easily delivered under pressure and spoils could easily be discharged to the canyons below. The method immediately proved to be an economic success, and improvements were quickly made to increase water supplies and pressure, and develop water cannons with advancements in nozzles, swivel joints, and deflectors to facilitate aiming the canon (Figure 7). Ultimately, hydraulic mining was augmented by blasting with dynamite and drift mining (tunneling from below) to discharge the overburden.

Water was a precious commodity during the hydraulic mining period, and large canal companies arose to deliver it along the ridges from snowmelt streams in the mountains above. By 1857, more than $7000 \mathrm{~km}$ of aqueducts had been completed to the mines of the Sierra Nevada (Holiday, 1981), including canals, trestles, bracket flumes attached to rock ledges, and reverse siphons (Figure 8). The geomorphic impacts of

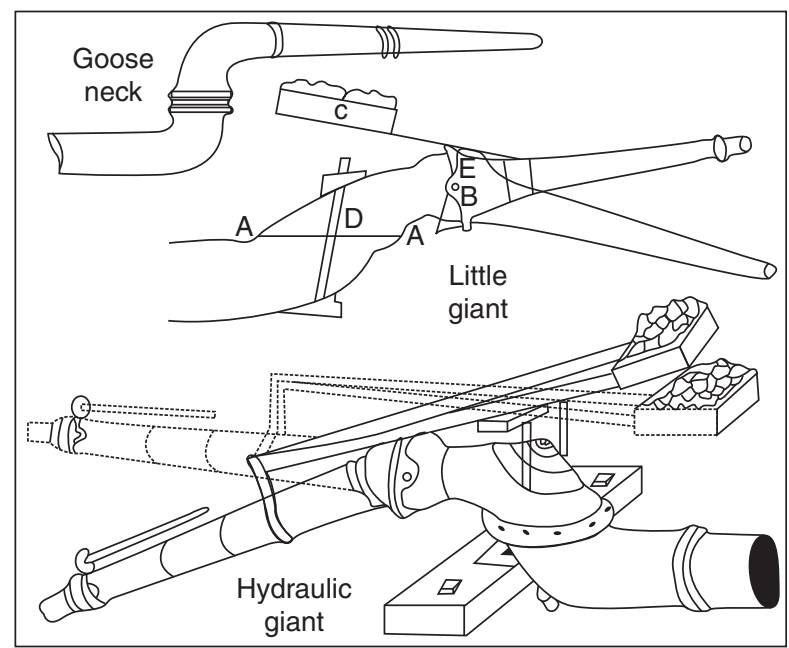

Figure 7 The rapid evolution of monitors (water cannons) for hydraulic mining in California from the mid-1850s through the 1870 s. Early canons used a simple goose neck, which proved dangerous as pressures increased. A series of improvements including ball joints allowed directional control in the vertical pivoting (E and $B)$ and horizontal rotation $(A)$ in the Little Giant, which quickly became a standard. Larger operations often adopted the Hydraulic Giant shown here with a deflector at the tip. Excerpted from Bowie, Jr. A.J., 1885. A Practical Treatise on Hydraulic Mining in California: With Description of the Use and Construction of Ditches, Flumes, Wrought Iron Pipes, and Dam. D. Van Nostrand. New York (Available on Google Books), with permission from Van Nostrand. hydraulic mining were immense and include generating large open-case mine pits (Figure 9) and aggradation, avulsions, and exacerbated flooding downstream in fluvial systems of the Central Valley (Gilbert, 1917; Kelley, 1959; James, 1989, 1991; James et al., 2009). Only in a region with a sparse population on the lowlands below could such an environmentally destructive technology be applied so freely. As agriculture became established in the Central Valley, hydraulic mining became a contentious political issue, and it was ultimately enjoined in 1884 by Lorenzo Sawyer, Judge of the Federal Ninth Circuit Court, in watersheds draining to navigable rivers (Woodruff $v$ s. North Bloomfield Mining and Gravel Company).

Some historically mined areas are becoming sites for tourism and historic preservation. Examples include the Wieliczka Salt Mine in Poland, the Völklingen Ironworks in Germany, the Blaenavon Industrial Landscape in the United Kingdom, and the mining area of the Great Copper Mountain in Falun (Sweden). The remains of a Roman alluvial gold mine at Las Médulas in Spain are so spectacular as to justify the site being designated UNESCO World Heritage status. In Belgium, the spoil heaps from coal mining are considered important landforms reflecting the sociocultural heritage of an

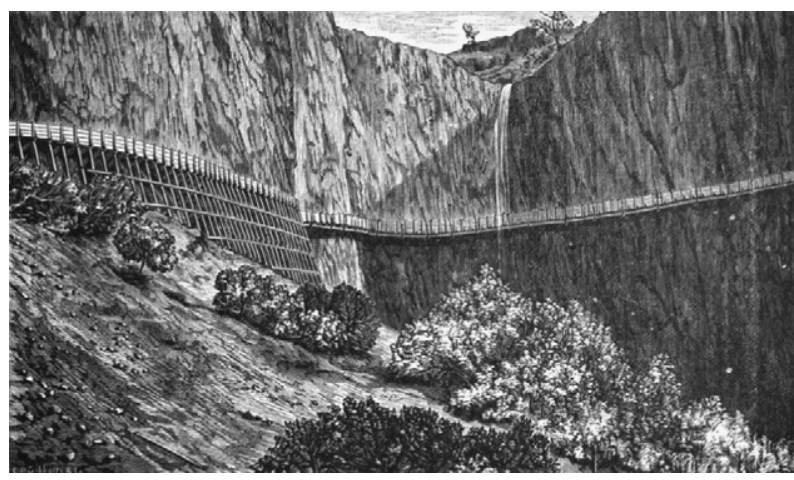

Figure 8 Bracket flume bolted to bedrock cliff face along Miocene Mining Company ditch in Butte County, CA. Reproduced from Bowie, Jr. A.J., 1885. A Practical Treatise on Hydraulic Mining in California: With Description of the Use and Construction of Ditches, Flumes, Wrought Iron Pipes, and Dam. D. Van Nostrand. New York (Available on Google Books), with permission from Van Nostrand.

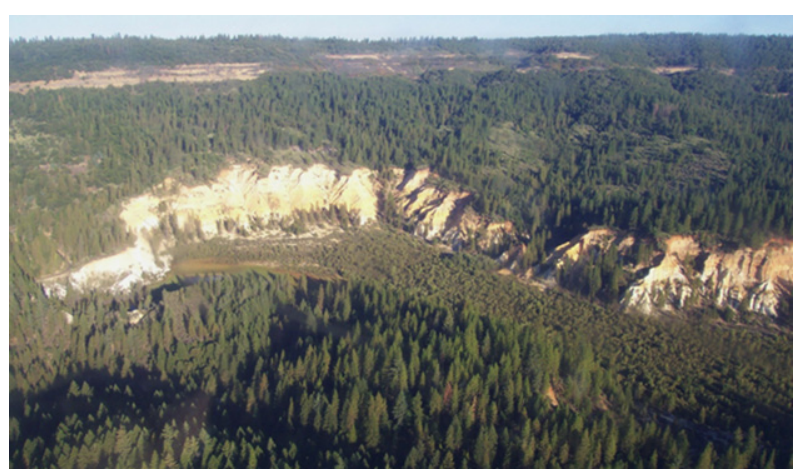

Figure 9 Malakoff Hydraulic mine pit on San Juan Ridge, northern California (photo credit: L.A. James). 
earlier industrial era, and are protected for their environmental value (Nyssen and Vermeersch, 2010). The terps, or artificial dwelling hills in the Netherlands, which are fill landforms that protected early dwellers in this area from flooding, have protected status for cultural and archeological reasons.

\subsubsection{The Current Scenario}

\subsubsection{Mineral Consumption and Comparison with Other Geomorphic Processes}

The extent and intensity of mining grew substantially during the industrial revolution. It has been estimated that the use of mineral resources increased 10-fold from 1750 to 1900 and another 13-fold from 1900 to 1990 (Johnson and Lewis, 1995: 204; Young, 1992). Global increases in production of various metals after 1700 were from 1 to 3 orders of magnitude (Figure 10). Per capita use of aggregate has increased from 1900, when it was $0.5 \mathrm{t}$, to nearly $10 \mathrm{t}$ in recent years (Langer et al., 2004). Mining is one of the main activities that results in material movement by humans currently being greater than that transported by natural processes (Hooke, 2000). An early estimate of the global extent of mining is that it covered more than a half million hectares in 1990 (Young, 1992). A spatially distributed estimate of anthropogeomorphic sediment production in the United States approximates that $3.8 \mathrm{Gt} \mathrm{a}^{-1}$ of sediment is produced by mining, compared with $3.0 \mathrm{Gt} \mathrm{a}^{-1}$ produced by paved road construction, $0.8 \mathrm{Gt} \mathrm{a}^{-1}$ by house construction, and $0.7 \mathrm{Gt} \mathrm{a}^{-1}$ by agriculture (Hooke, 1994). Considering that road and house constructions are largely supported by sand and gravel production, mining has become an important geomorphic process in the modern industrialized world. Sediment production from mining varies spatially, with the highest US values in West Virginia and Pennsylvania, where coal mining directly

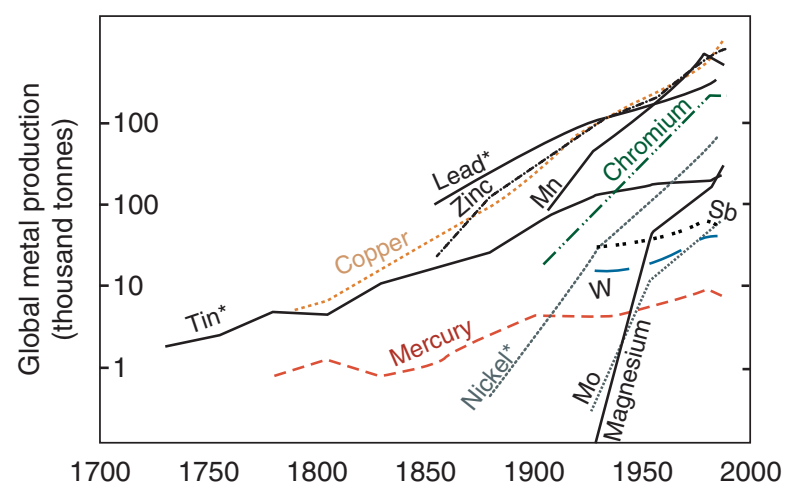

Figure 10 Exponential increases in metal production over the past 200 years. Chemical abbreviations are manganese $(\mathrm{Mn})$, antimony $(\mathrm{Sb})$, tungsten (W), and molybdenum (Mo). Adapted from Brown, H.S., Kasperson, R.E., Raymond, S.S., 1990. Trace Pollutants. In: Turner, II B.L., Clark, W.C., Kates, R.W., Richards, J.F., Mathews, J.T., Meyer, W.B. (Eds.), The Earth as Transformed by Human Action: Global and Regional Changes in the Biosphere over the Past 300 Years. Cambridge University Press, Cambridge, pp. 437-454. and indirectly removes large volumes of sediment (Figure 11 and Table 3).

Sand, gravel, and stone are the materials extracted in the largest amounts, and quantities extracted annually vary with the economy, in particular, the construction industry dwarfs consumption of other products (Minerals Information Institute, 2011; Figure 12). Worldwide, the annual production of aggregate totals about 15 billion metric tons (Langer et al., 2004). This far exceeds the production of all other materials. Fossil fuels, such as coal, petroleum, and natural gas, are also in high demand. Other essential minerals include cement (mixture of lime and pozzolan), salt, phosphate, iron ore, and clays. A variety of other base metals, such as bauxite, copper, lead, and zinc are important, as are many precious metals such as gold and silver (Figure 12). Although the United States is well known for the consumption and production of mined commodities, other countries are now surpassing the United States in terms of production and potential impacts, even though some of these products are exported. China, which has a fast-growing economy, is the world's number-one producer of coal and varied industrial minerals, including cement,

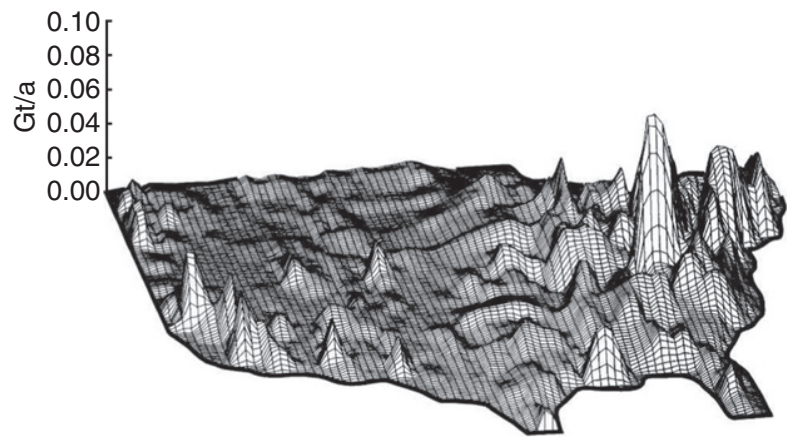

Figure 11 Total anthropogeomorphic sediment in United States, including mining, paved road construction, house construction, and agriculture. Reprinted from Hooke, R., 1999. Spatial distribution of human geomorphic activity in the United States: Comparison with rivers. Earth Surface Processes and Landforms 24, 687-692, with permission from Wiley.

Table 3 Coal production from surface mines in select states and regions, 2008

\begin{tabular}{lcc}
\hline State/region & $\begin{array}{c}\text { Production } \\
(t \times 1000)\end{array}$ & $\begin{array}{c}\text { Percent production of } \\
\text { all US surface mines }\end{array}$ \\
\hline Wyoming & 421063 & 57.1 \\
Appalachia $^{a}$ & 143512 & 19.4 \\
Kentucky (east and & 46273 & 6.3 \\
$\quad$ & & \\
Kest) & 41966 & 5.7 \\
Wentucky (east only) & 63162 & 8.5 \\
West Virginia & 740123 & 100
\end{tabular}

Includes eastern Kentucky and West Virginia.

Source: Reproduced from Government Accounting Office (GA0), 2009. Surface Coal Mining: Characteristics of Mining in Mountainous Areas of Kentucky and West Virginia. GA0-10-21. Washington, DC 
Every American born will need...

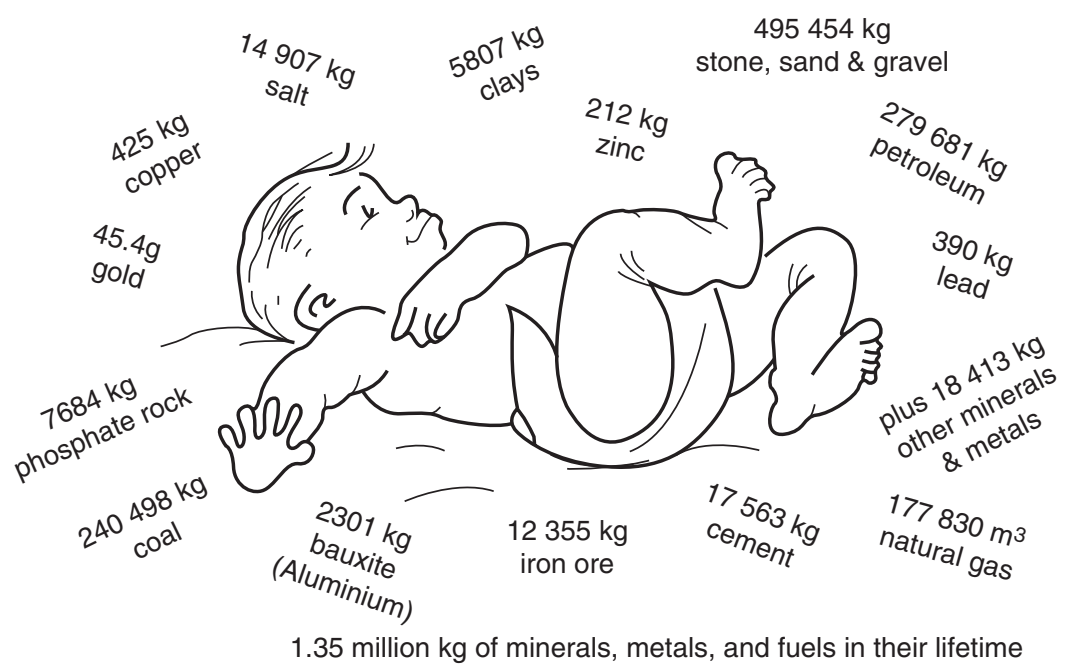

Figure 12 Current consumption of various minerals, metals, and fuels by US citizens. On average, US citizens consume more resources than those of most other countries, but China is the world's number-one producer of coal, and varied industrial minerals, including cement, fluorspar, and rare earths, and is the top or amongst the top producers in a number of metals.

fluorspar (fluorite), and rare earths, and is at the top or among the top producers of a number of metals (Menzie et al., 2004).

\subsubsection{Mining Landscapes and Landscape Change}

\subsection{Comparisons of landscapes, waste rock, and geography}

Mined landscapes have many features in common such that they are readily recognizable, but also have some important differences associated with the scale of operation, the material being extracted, and characteristics associated with the particular site. First, they usually convert surfaces to bare earth. Much waste rock is generated by mineral extraction; with some raw materials it is $50 \%$ of what is produced, but with rare minerals the proportions are much higher (Nir, 1983). Copper production generates $98 \%$ waste rock, and gold mining creates over $99 \%$ waste rock in the process (Nir, 1983). However large an individual mine is, the impact of a single mine does not compare to the collective or the potential effect of the larger industry. In the United States and other developed countries, over $90 \%$ of the mines are open pits, whereas, in less-developed countries, about 50\% of the mining is underground (Kesler, 1994). This disparity is largely explained by more costly labor required for underground mining and lower labor costs in less-developed countries. The way in which mining changes landscapes varies considerably with the product being mined, although some industries have a wider variety of landscape changes than others. Landscape alteration, exemplified by stone quarrying, has been classified by the nature of resulting surface features, by whether it produces excavated or accumulated forms, by their origin and size, by simplicity or complexity, and by the type of geotechnic activity (Dávid, 2010). Especially in areas with high-water tables, more surface water bodies may be present at the end of operations. Stream channels may be destroyed in one way or another, and groundwater tables may be lowered.

\subsection{Open pits}

Open-pit mining for copper, diamonds, gold, and other precious metals has created some amazing landscapes (Figure 2). Some of the world's largest pits, listed in Table 4, result in a variety of unique above-ground and below-ground landscapes. Several large pits are over $1 \mathrm{~km}$ deep. The deepest operating mine in the world is the Western Deep Levels gold mine near Carletonville, South Africa, which has reached a depth of $3466 \mathrm{~m}$ (Kesler, 1994) and is now about $3.9 \mathrm{~km}$. Although most of these were created using heavy equipment, Big Hole in South Africa was hand dug by 50000 miners from 1871 to 1914. Deep open-pit mines typically have multilevel horizon mining with stair-step spiraling benches that are designed to prevent landslides and act as roadways, creating unique landforms that are unlike depressions created by natural processes.

\subsubsection{Coal-Mining Landscapes}

Coal mining is a major geomorphic activity (Table 3 ) in the United States. Even though most surface coal mining is in Wyoming, and Appalachia mines primarily in West Virginia and Kentucky produce about one third as much, there is great concern about transforming landscapes in the US Appalachian mountains (Saylor, 2008), and many scientists are particularly concerned about the practice of mountaintop mining with valley fills (Palmer et al., 2010). Following removal of forest and overburden, explosives are used to break up rocks to access buried coal, removing over $160 \mathrm{~m}$ off the tops of mountains and resulting in the loss of over $5000 \mathrm{~km}^{2}$ of deciduous forest (US Environmental Protection Agency, 2010). Excess rock is dumped into adjacent valleys, and debris has 
Table 4 Some examples of the world's largest and deepest mines (sources include Kennecott and Bukisa)

\begin{tabular}{lll}
\hline Name & Location & Dimensions and facts \\
\hline Bingham canyon copper mine & Utah, USA & $7.7 \mathrm{~km}^{2}, 4 \mathrm{~km}$ wide, $1.2 \mathrm{~km}$ deep \\
Hibbing iron ore mine & Minnesota, USA & $8.1 \mathrm{~km}^{2}, 165 \mathrm{~m}$ deep \\
Tautona gold mine & Carletonville, South Africa & $3.9 \mathrm{~km}$ deep \\
Chuquicamata copper mine & Antofagasta Region, Chile & 5 by $3 \mathrm{~km}, 1 \mathrm{~km}$ deep \\
Mir diamond mine & Myrny, Siberia, Russia & $1.2 \mathrm{~km}$ wide, $525 \mathrm{~m}$ deep \\
Big hole diamond mine (hand dug) & Kimberly, South Africa & $17 \mathrm{ha}\left(0.17 \mathrm{~km}^{2}\right), 463 \mathrm{~m}$ wide, $240 \mathrm{~m}$ deep \\
Super pit & Kalgoorlie, Western Australia & $3.6 \mathrm{by} 1.6 \mathrm{~km}, 512 \mathrm{~m}$ deep \\
Palabora copper mine & Northeastern South Africa & $2 \mathrm{~km} \mathrm{diameter,} \mathrm{bottom} \mathrm{over} 230 \mathrm{~m}$ below sea level \\
East rand gold mines & South Africa & $48.6 \mathrm{~km}^{2}$, over $4000 \mathrm{~km}$ of tunnels \\
Potosi silver mine & Bolivia & Located at $6000 \mathrm{~m}$ elevation \\
Sifto salt mine & Goderich, Ontario, Canada & $2.5 \mathrm{~km}$ wide, $530 \mathrm{~m}$ deep, goes $3.2 \mathrm{~km}$ under L. Huron \\
\hline
\end{tabular}

Source: http://www.kennecott.com/visitors-center/, http://www.bukisa.com/articles/218700_worldslargest-open-pit-mines\#ixzz1GDMBJxHI

been placed in over $1100 \mathrm{~km}$ of headwater streams, increasing runoff as well as the frequency and magnitude of downstream flooding (Palmer et al., 2010).

In the Central German mining district, eight billion tons of lignite have been extracted, entailing the movement of 20 billion $\mathrm{m}^{3}$ of overburden and another 20 billion $\mathrm{m}^{3}$ of water (Hildmann and Wonsche, 1996). One of the biggest landscape changes is the distribution of water and land. Lignite extraction creates huge pits, which are intentionally flooded to become lakes. The total surface area of such lakes in Central Germany is currently about $110 \mathrm{~km}^{2}$ in a mined area of $610 \mathrm{~km}^{2}$ area, but an area of about $1100 \mathrm{~km}^{2}$ has experienced a lower water table. Reclamation of the area is producing a functional but altered postmining landscape that has very different soil, topography, microclimate, and geological substrata than before.

\subsection{Phosphate-mining landscapes}

In a very different setting, the Florida phosphate industry, which supplies most of the United States and 25\% of the world, owns or has mineral rights to about $1800 \mathrm{~km}^{2}$ land. More than a century ago, in 1881, unconsolidated phosphate deposits were discovered on the riverbed of the Peace River. The industry grew rapidly and more than $100000 \mathrm{t}$ of pebble phosphate was extracted annually by 1892 , with $12-15$ dredges averaging 35-45 t/day apiece (Hoyer Millar, 1892). Miners commonly dredged along anabranches or secondary channels that had been recently avulsed or abandoned as the river naturally shifted course, and operations characteristically worked well into the river banks, exposing pebbles buried under sandy natural levees. According to Holland and Knight (1980), a US Army Corps of Engineers inspector examined the river in 1917 and stated, "These companies dredged basins and slips to reach their land, made cutoffs in the river, threw up dams to create pools for dredging by flooding the lands, all resulting in changing the courses of the channel, creating many bad shoals, and leaving the river in a very bad condition."

Technology has made phosphate mining more efficient, such that one dragline can mine $73 \mathrm{ha} \mathrm{a}^{-1}$, removing 5-15 m of overlying material to extract $1.5-6 \mathrm{~m}$ of matrix (clay, sand, and phosphate rock; Figure 13). In the process of extracting such material, large areas of headwater streams are removed.
Reclamation is a big challenge, as the sediments replaced after phosphate extraction take years to settle, then require topsoil, vegetation, and, in places, creation of a new drainage network and water bodies (Figure 13). Another challenge entails what to do with leftover phosphogypsum, a mildly radioactive waste from the fertilizer plants, which is stored in flat-topped hills, up to $60 \mathrm{~m}$ high, called gypstacks. As of 1996, $10^{9} \mathrm{t}$ of phosphogypsum was stored (Hull and Burnett, 1996), and an estimated $30 \times 10^{6} \mathrm{t}$ is added to those stacks in this low-relief area every year.

\subsection{Oil extraction landscapes}

In another lowland, the coastal wetlands of Louisiana, dredging of canals for oil and gas exploration as well as access and transport of hydrocarbons has converted many marshes to water, contributing to the land loss in a state that has $80 \%$ of the nation's total wetland losses (Dahl, 1990). Canal dimensions are typically $2.5 \mathrm{~m}$ deep, $20-40 \mathrm{~m}$ wide, and vary from $100 \mathrm{~m}$ to several $\mathrm{km}$ long (Turner et al., 1994). One estimate of the total length is $20000 \mathrm{~km}$ (Getschow and Petzinger, 1984). Detailed map interpretation suggests that canal dredging was directly responsible for $12 \%$ of the total land losses, which reached a peak rate of $109 \mathrm{~km}^{2} \mathrm{a}^{-1}$ from 1958 to 1974 (Britsch and Dunbar, 1993), or $13 \mathrm{~km}^{2} \mathrm{a}^{-1}$. Moreover, by altering the hydrology and vulnerability of the landscape to storms, these canals are likely indirectly responsible for some of the remaining wetland loss. By 1978-2000, land-loss rates decreased to $77 \mathrm{~km}^{2} \mathrm{a}^{-1}$ (Barras et al., 2003), in part due to wider recognition of this problem and more emphasis on directional or directed drilling, where a single access point is used to drill in a variety of directions. The process of canal building has created a very unique crisscross landscape from the air (Figure 14), making the coastline more vulnerable to storms, and resulting in circular canals around structural features such as surface and subsurface salt domes.

Extraction of oil and gas in Louisiana and other regions also affects landscapes by the connections created between surface forms and subsurface processes. Fluid withdrawal can accelerate sediment compaction, dewater clays, reactivate faults, or trigger sinkholes, especially in coastal lowlands. Hot spots of surface land loss in coastal Louisiana have been linked with large-volume fluid production from nearby hydrocarbon fields; former marshes lie $1 \mathrm{~m}$ under water 

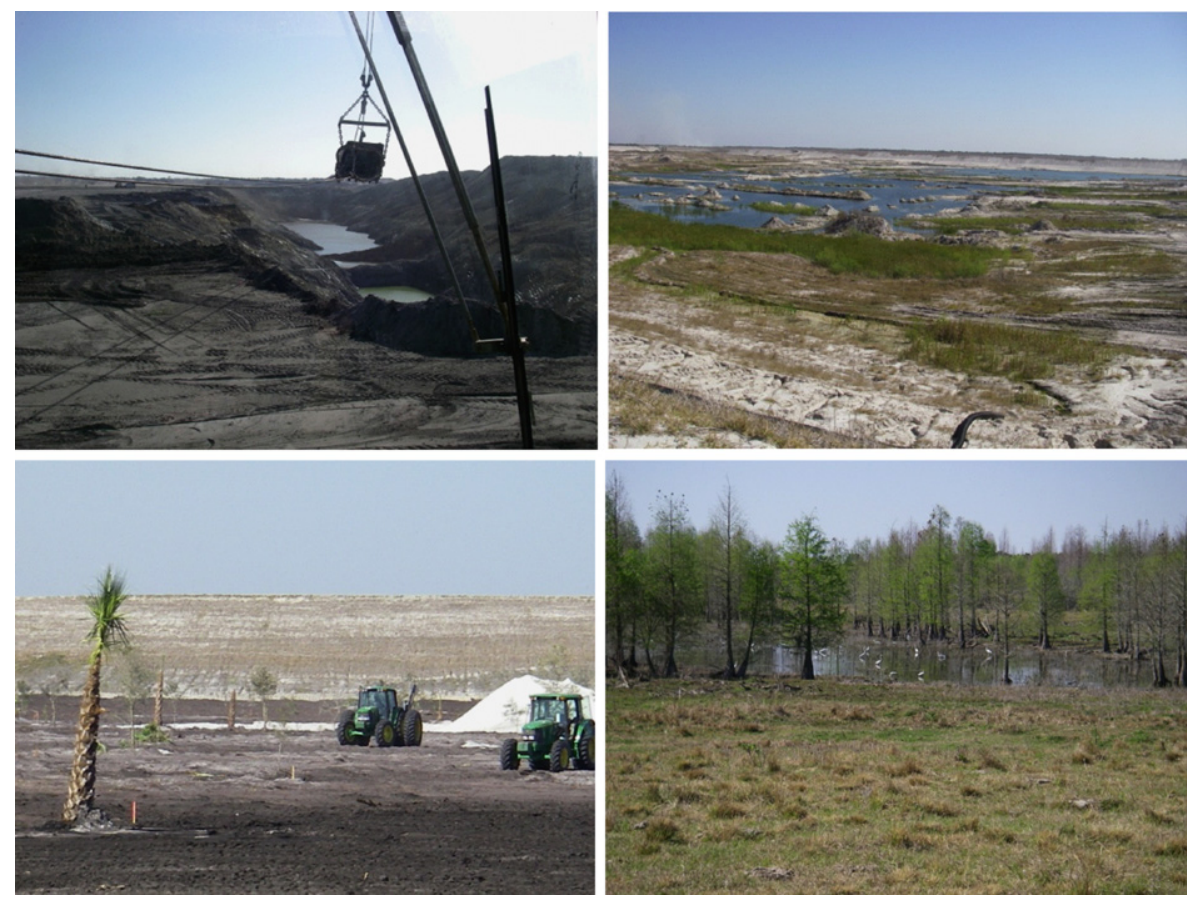

Figure 13 Landscapes of phosphate extraction and reclamation, Florida. Top: Left photo shows dragline that carries $55 \mathrm{~m}^{3}$ of sediment while removing overburden and extracting phosphate. Right photo shows a former phosphate mine being slowly drained for reclamation; lower: left photo shows active reclamation by adding topsoil and plants. Right photo shows landscape reclaimed following phosphate mining, which is now a pond with wading birds (photo credits: J. Mossa).
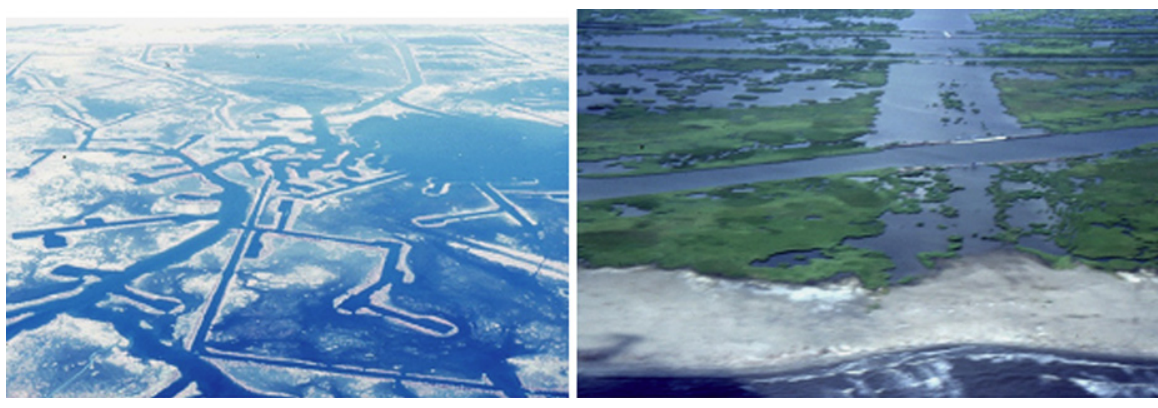

Figure 14 Landscapes of mineral extraction, Louisiana. Left shows how canal construction for petroleum extraction in coastal wetlands has contributed to large amounts of land loss. Right shows that canal construction normal to the shoreline makes barrier shorelines more prone to overwash, whereas canal construction parallel to shoreline acts as a sink for sediment in landward-migrating barrier beaches (photo credits: J. Mossa).

because of 10 times more subsidence than in the surrounding areas (Morton et al., 2003). Subsidence bowls vary greatly in dimension. Of the depressions attributed primarily to hydrocarbon withdrawal, one is $3 \mathrm{~m}$ deep across more than $12000 \mathrm{~km}^{2}$ of southeastern Texas, resulting in the flooding of Baytown (Morton, 2003), and another is $9 \mathrm{~m}$ deep, covering $35 \mathrm{~km}^{2}$ near Long Beach, CA (Poland and Davis, 1969; Chilingar and Endres, 2005).

Although a large portion of the petroleum reserves in Alaska is offshore, the transport of oil can also lead to pronounced geomorphic transformations. One notable example is the Trans-Alaska pipeline, a somewhat controversial feature nearly $1300 \mathrm{~km}$ in length that crosses delicate permafrost terrain, is buried under small stream crossings, and passes over larger rivers with bridges. In addition, this fragile landscape is traversed by a road, made partly of gravel and built to support and access the pipeline and its employees, who operate pump stations, maintain the pipeline, and deal with problems.

\subsection{Sand and gravel-mining landscapes: Rivers and floodplains}

Because it is needed for so many construction purposes in such large volumes, sand and gravel extraction is a widespread activity along river channels throughout the world, especially close to growing urban areas. In locations distant from bedrock and glacial deposits, fluvial deposits may be the best or the only source of aggregates. In-stream and floodplain mining can be a small-scale activity using shovels and 


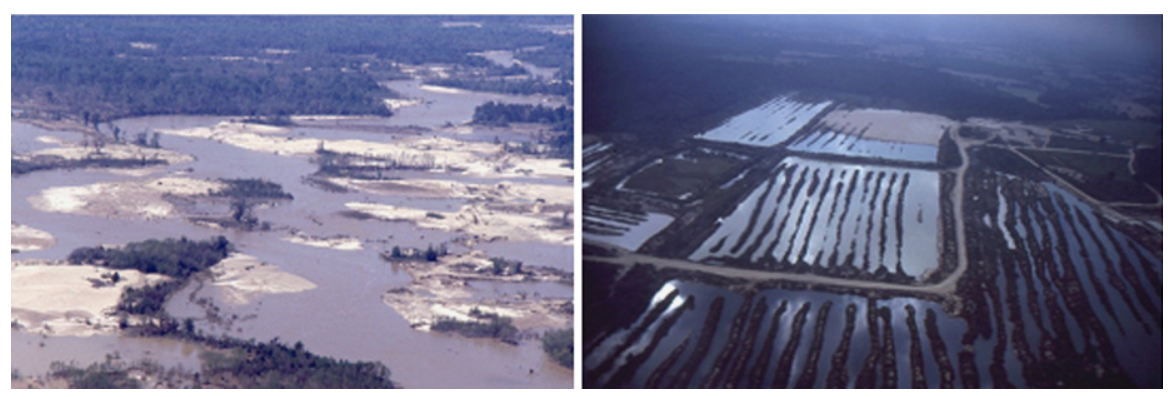

Figure 15 Left photo shows that gravel mining in Amite River floodplain creates various stock piles, fans, pits, and paths for the channel to reroute during the April 1983 flood. Right shows large furrows and fans (back center) created by sand and gravel mining in the Tangipahoa floodplain (photo credits: J. Mossa).

wheelbarrows (e.g., Harden, 1993, 2006; deLeeuw et al., 2010) or a large-scale endeavor using heavy equipment, including hydraulic dredges. Small-scale, in-stream operations tend to modify channel bars and the cross-sectional form of the channel; larger operations can radically alter the stream and floodplain form, creating several pits and ponds (Figure 15). Including upland aggregate mines, approximately 9900 pits and quarries in the United States over what time period does this statistic apply? more than 2.7 billion tons of sand, gravel, and crushed stone (Bolen, 2002; Tepordei, 2002; Arnold et al., 2003). An estimated $10-20 \%$ of sand and gravel mined in the United States in 1974 was taken from streams (Newport and Moyer, 1974). Since the passage of Section 404 of the Clean Water Act Amendments of 1977, some states have heavily restricted in-stream mining; thus this number may have decreased. Approximately 14 million $\mathrm{kg}$ of aggregate is required for the construction of a school or a hospital and $91000 \mathrm{~kg}$ for a typical 6-room house (Langer 1988, Meador and Layher, 1998). At a bulk density of $2000 \mathrm{~kg} \mathrm{~m}^{-3}$, these masses represent approximately 7000 and $45 \mathrm{~m}^{3}$ of aggregate, respectively, and this calculation underestimates the amounts mined because it does not account for overburden and other waste materials.

Mining of coarse-grained alluvium from and along rivers causes geomorphic, hydrologic, and biotic changes. Besides direct changes, the bare and irregular topography of the landscape is vulnerable to change during flood events. Planform and position changes include increased bank erosion, lateral migration, and channel shifting when the river avulses into floodplain pits. Mined reaches can widen from material extraction along the channel perimeter or by capturing the anthropogenic form of a pit through migration or avulsion (Mossa and Marks, 2011). Degradation, which can extend to channel incision of several meters, is a common response to mining the channel bed (Kondolf, 1994; Davis et al., 2000; Marston et al., 2003; Uribelarrea et al., 2003). Degradation within and adjacent to mined reaches results in reduced flood stages, but at some distance downstream of mined reaches, aggradation from excessive sediment inputs can increase the frequency and magnitude of overbank flows (e.g., Gilbert, 1917; Brim-Box and Mossa, 1999).

An avulsion into one or more floodplain pits (Scott, 1973; Bull and Scott, 1974; Kondolf, 1994; Brown et al., 1998; Sandecki, 1989; Mossa, 1995; Wampler et al., 2006) can have the same effect as in-stream mining, because these along-channel pits can trap much of the bed load transport for decades. In spite of the presence of dikes or revetments in Washington state, USA, stream captures in floodplain pits are commonplace (Norman et al., 1998). An avulsion that goes through a long reach of channel, such as the one that went through several pits on Big Escambia Creek, FL, can shorten the length and shift the location of tributary junctures by several kilometers (US Army Corps of Engineers-Mobile District, 2000). This practice is poorly regulated United States in the Unit, and not regulated or not well policed in a number of other locations.

Besides changing the channel form, the legacy of mining sand and gravel in rivers and floodplains includes a preponderance of lakes and water bodies. In areas of rapid sedimentation, there are potential positive effects, including reduced flood stages and related damages, such as on rivers in China (deLeeuw et al., 2010). Because mining for sand and gravel in rivers and floodplains is so widespread, most impacted rivers have not been studied, and more work is needed to evaluate and better understand the extent of the activity and its geomorphic effects worldwide.

\subsection{Sand and gravel-mining landscapes: Coasts and lakes}

Sand, gravel, and stone are mined from beaches and coastal areas, mostly for use in construction including fill, building sand, and building lime (Clark, 1996). Modern beach and dune sands may contain heavy minerals such as titanium and zirconium (Mulaba-Bafubiandi et al., 2002; Panigrahi, 2005; Ghosh et al., 2006) that were sorted dominantly by winds. These heavy minerals, used in paints and industrial applications, also occur in Pleistocene beach deposits (Pirkle et al., 2005). Mining of beach sands for diamonds occurs along and off the Namibian coast (McLachlan, 1996; Theron et al., 2003).

Sediment mining of modern beaches and dunes adversely affects coastal habitat, alters the sediment budget, and hastens erosion. Many studies acknowledge this as a factor in contributing to enhanced erosion (Masalu, 2002; Thornton et al., 2006). One study suggests that sand and gravel mining, from the coast and coastal watersheds combined, is the primary anthropogenic cause of sediment loss to the littoral zone on the US west coast, followed by dams (Magoon and Lent, 2005). Sediment removal may also alter particle size 
distributions, changing the morphodynamic state of beaches (McLachlan, 1996).

It is now illegal in many countries to remove sand from the littoral active zone (Clark, 1996), and many Americans would be surprised to know that the beaches of California and Oregon were mined from the late 1800s until 1991, when it was banned (Magoon and Lent, 2005). For example, locations near Monterey, CA, are intensively mined, with $128000 \mathrm{~m}^{3} \mathrm{a}^{-1}$ of sand removed directly from the surf zone on average (Thornton et al., 2006), and mining of coastal dunes for material to replenish beaches after storms is still allowed. Sediment inputs are also reduced by mining of coastal watersheds, at a rate of $11 \times 10^{6} \mathrm{t} \mathrm{a}^{-1}$ from northern California rivers, and $55.8 \times 10^{6} \mathrm{t} \mathrm{a}^{-1}$ is being extracted in southern California (Magoon and Lent, 2005).

A database compiled from varied media reports, websites, and journals (Young and Griffith, 2009) documents coastal sand mining in 35 countries on six continents. They note that sand mining in many localities has resulted in the complete destruction of beaches and related ecosystems, along with severe impacts to coastal protection and tourism. When coastal sands are mined for construction in developing countries, it creates a predicament for the local economy. In Ghana, mining is supporting coastal development, but aggravating coastal erosion (Mensah, 1997; Masalu, 2002; Cho, 2006; Pousa et al., 2007). Although most governments recognize the local impacts of sand mining and mining activities are illegal in many localities, enforcement of these protections has been problematic and requires pressure to stop the practice from local or international environmental groups. More problematic is when mine tailings are left on beaches.

Beach nourishment is a form of mining practiced worldwide, but primarily in developed countries and tourist areas. It involves taking sand mostly from offshore and tidal deltas and using it to build beaches for storm mitigation and recreational purposes. From 1923 to $1999,268 \times 10^{6} \mathrm{~m}^{3}$ of sand has been deposited on the US East Coast barrier island shorelines from Long Island, NY, to Fisher Island, FL, by more than 573 beach nourishment episodes at 154 locations (Valverde et al., 1999). Most of this volume (65\%) was placed by federally sponsored beach nourishment projects. Both the source and destination areas are altered in form from this activity, resulting in varied environmental consequences (Adriaanse and Coosen, 1991). Nourishment is also widely practiced in Europe, where Hanson et al. (2002) documented $348 \times 10^{6} \mathrm{~m}^{3}$ of beach nourishment in seven countries since 1951, with the Netherlands and Spain leading at $110 \times 10^{6} \mathrm{~m}^{3}$ apiece. This process has led to the intentional building of anthropogenic landforms, such as in the Netherlands, where large areas are protected by a massive artificial dune. A comparison of recent annual fill rates in selected countries puts the United States in the lead at $30 \times 10^{6} \mathrm{~m}^{3} \mathrm{a}^{-1}$, followed by Spain at $10 \times 10^{6} \mathrm{~m}^{3} \mathrm{a}^{-1}$, the Netherlands at $6 \times 10^{6} \mathrm{~m}^{3} \mathrm{a}^{-1}$, and then Japan and South Africa at $5 \times 10^{6} \mathrm{~m}^{3} \mathrm{a}^{-1}$ each. Other countries, including Italy, Denmark, the United Kingdom, and Australia, also have estimated beach nourishment rates of $1 \times 10^{6} \mathrm{~m}^{3} \mathrm{a}^{-1}$ or higher (Hanson et al., 2002). In many places, sand is mined offshore, commonly on the outer shelf; the ecological impacts of this activity are probably slight for beaches, but not well understood (Byrnes et al., 2004).

\subsection{Sand and gravel-mining landscapes: Glacial deposits}

Sand and gravel are also abundant in areas covered by glaciers during the Pleistocene. Glaciofluvial deposits are commonly stratified, as meltwater-sorted sedimentary materials. Thus, landforms such as outwash plains, kames, and eskers provide desirable materials for construction as the clay content is low, facilitating the washing and sorting that accompanies aggregate processing. Unsorted deposits such as moraines can be a good source of fill dirt.

Patterns of sediment deposition indicate shifts in streamflow direction, volume, and velocity associated with the melting glaciers. Because of the environmental problems associated with mining dunes in Michigan, Schrotenboer and Arbogast (2010) investigated several alternative glacial outwash and inland dune sites that had potential for use as foundry sand, and less potential to adversely affect the local natural resources. If not amenable to use in foundries, the inland sand could be used for other purposes.

\subsubsection{Mining and Geomorphic Hazards}

\subsubsection{Above-Ground Hazards}

\subsection{Mining and hillslope failures}

Varied mining practices result in loose sediments on steep slopes; combined with the use of dynamite, this can result in the initiation of first-time slope movements and the reactivation of failures at sites where mass wasting occurred previously. The larger failures with fatalities in developed countries are generally well documented, but fatal landslides at mines in developing countries are less well reported. Several of these have occurred in China, where resource production and consumption have grown considerably. To some extent this is a human rights issue, as many mines do not have safety licenses, use explosives, operate illegally, and leave waste piles that are sites of potential danger. Some countries that have recently had failures at mines that resulted in fatalities include Chile, Malaysia, Ghana, Columbia, Myanmar, and Turkey.

\subsection{Mine tailings and tailings dams failures}

Where extensive, mine tailings may introduce geochemical changes (Lewin et al., 1977; Knox, 1987; Leenaers, 1989; Macklin, 1996; Lecce and Pavlowsky, 1997; Marcus et al., 2001; Hudson-Edwards et al., 2003; Macklin et al., 2006) as well as increased sediment loadings and morphological effects to fluvial systems downstream (Gilbert, 1917; Lewin et al., 1983). Study of the long-term fate of mine tailings as contaminants in fluvial systems involves an integrated geomorphological-geochemical approach. This approach assumes that metals associated with sediment are transported along the same trajectories as those of other elements bound to the particles. This assumption allows patterns of deposition and storage to be predicted based on the geomorphology of floodplains (Knox, 1987; Graf, 1994; Macklin, 1996; Miller, 1997; Hudson-Edwards et al., 2001, 2003). In recent decades, mining regulations in developed nations have reduced flagrant releases of metals to the environment, but dangerous levels of toxic metals continue to be released in some places. In Latin 
America, for example, a large number of small-scale twentiethcentury artisanal miners introduced approximately $5000 \mathrm{t}$ of elemental mercury during gold mining (Arnell, 2002).

Tailings dam failures are not uncommon, as shown by a recent synthesis of the known historical cases including 147 cases of worldwide tailings dam disasters compiled in a database (Rico et al., 2008a, b). Common causes include unusually intense rainfall, poor engineering of dams, and seismic liquefaction. A preponderance of incidents (over 90\%) occurred in active mines, and only $10 \%$ occurred on abandoned sites, suggesting an urgent need for regulations. Rico et al. (2008a) noted that their database is likely to be very incomplete and biased toward developed nations, since the majority of tailings dam incidents remain unreported, especially in developing countries or in those countries where environmental legislation is, or has been, very lax. In those cases where a known accident did occur, it is generally difficult to obtain basic information regarding the tailings dam and its condition prior to the incident; thus, the database reflects the lack or abundance of information from individual countries, rather than the actual number of incidents. As a result, the database documents that $74 \%$ of the cases come from a small number of locations: USA (39\%), Europe (18\%), Chile $(12 \%)$, and the Philippines (5\%). In Europe, out of the 26 cases compiled, 38\% occurred in the UK and 56\% are distributed between nine other countries (Bulgaria, France, Ireland, Italy, Republic of Macedonia, Poland, Romania, Spain, and Sweden).

Europe has had several disasters associated with landslides in tips and failures of mine-waste tailings dams. In North Bulgaria at the Mir mine, which extracted zinc, lead, and possibly uranium, an embankment at a waste pond collapsed, due to heavy rainfall combined with poor dam construction. The resulting flood killed 488 people in the village of Sgorigrad on May 1, 1966. The Communist government attempted to suppress the news of the disaster, seizing photographs and changing the death count. An unstable coal heap in the mining village of Aberfan, Wales, was built over a series of springs. On October 21, 1966, a landslide of these waste materials, which was triggered by heavy rain, buried a primary school, killing 116 children and 28 adults (Johnes, 2000; Sütö, 2010). At the time of disposal, no environmental impact assessment was made, and the waste was piled on a steep slope above the village in a pile between 40 and $200 \mathrm{~m}$ in height. A few decades later, not far away in Italy, on July 19, 1985, a fluorite tailings dam first started leaking, then breached, leading to the collapse of a lower dam. About $40000 \mathrm{~m}^{3}$ of water was added to $150000 \mathrm{~m}^{3}$ of debris from the retaining walls of the dams, and this admixture picked up more than $100000 \mathrm{~m}^{3}$ of debris, creating a fast-moving debris flow down the Stava Valley and resulting in over 200 deaths (Alexander, 1986). Even without direct deaths, environmental damages may be extreme. For example, the April 25, 1998, collapse at the Swedish-owned pyrite mine at Aznalcóllar, Spain, caused such environmental destruction that local universities and municipalities used a SWOT approach (Strengths, Weaknesses, Opportunities, Threats) to evaluate problems (Guerrero et al., 2008).

Floods from tailings ponds failures are an additional problem, whether fatal or not, as there are serious long-term environmental effects. Rico et al. (2008a, b) were able to document 29 historic tailings dam failures worldwide that occurred between 1965 and 2000, using the characteristics of these with statistics and an envelope curve to better understand the causes of past disasters and potential risk of potential future disasters. On the night of 22 February, a tailings dam failure flooded the suburb of Merriespruit, Virginia, Free State, South Africa, causing 17 deaths and widespread devastation and environmental damage. Contaminated sediments from such failures persist long after mine closure, exemplified by metal contamination from sulfide ore mining in the headwaters of a creek in Yellowstone National Park. Although the tailings dam failure occurred in 1950, floods remove some sediment through bank erosion and bring new sediments from mine waste, causing no net change in concentrations (Marcus et al., 2001) and suggesting long-lasting impacts in similarly affected streams worldwide.

Rivers are also susceptible to change from above-ground mining activities. Dumping overburden from coal mining directly within the river channel heightened a flood in 2006 in the Erai River watershed of Chandrapur district in Maharashtra, India (Katpatal and Patil, 2010) by reducing the channel capacity. Thus, this area is at greater flood risk due to heavy rainfall. The practice of overburden dumping in streams is not recommended and this applies to valley fills from mountaintop mining of coal in the US Appalachians.

\subsubsection{Below-Ground Hazards}

\subsection{Underground mining and subsidence}

Salt extraction has been implicated as a cause of up to $12 \mathrm{~m}$ of subsidence in Tuzla, Bosnia, and Herzegovina, resulting in damage to historic buildings and infrastructure (Mancini et al., 2009). German underground coal mining, especially in the North Rhine-Westphalia region, has damaged thousands of houses, and coal-mining companies have set aside many millions in funding for future subsidence damages as part of their insurance and state subsidy schemes. A suspected coal mine collapse in the German Saar region in 2008 created an earthquake of force 4.0 on the Richter magnitude scale, causing some limited damage to houses.

Mining and subsidence are closely connected, no matter the form of the deposit. Some examples include the mining of chalk in southern England, the collapse of slate mines and caverns in Germany, the underground extraction of evaporites in Northern Ireland, fault reactivation in Wales and northern England, and the extensive extraction of pumice on the flanks of Galeras volcano in Colombia (Bell et al., 2005). In Hungary, hydrocarbon extraction caused a depression with a maximum depth of $40 \mathrm{~m}$ in the vicinity of Debrecen (Sütö, 2010). Evidence of subsidence at the surface may be seen in the form of cracks in structures, tension cracks in soils, or subsidence pits, which are similar to dolines in karst terrain. Water tables may drop irreversibly and groundwater permeabilities may increase by an order of magnitude (Sgambat et al., 1980).

\subsection{Catastrophic floods in underground mines}

Most mining-related floods are caused by collapse of detention works at the surface, but floods are also a great danger to 
miners in underground mines. Such was the case with a tragedy at East Wheal Rose, an underground mine about $5 \mathrm{~km}$ inland from the north Cornwall coast, United Kingdom. The mine mainly produced lead ore (galena), but commercial quantities of silver and zinc were also found and sold. The mine was situated in the valley of a small stream, with the deepest workings almost $300 \mathrm{~m}$ below the surface. An unusually heavy thunderstorm on July 9, 1846, caused water to enter the shafts and flood the mine to the $100 \mathrm{~m}$ level, drowning 39 of the 200 miners who were underground at the time (Rule, 1998).

Underground mining activities can inadvertently result in some type of collapse, resulting in sinkholes and other collapse features. One such collapse occurred on November 20, 1980, due to the combination of salt and petroleum mining on Jefferson Island, one of several salt domes or diapirs, with surface expression in southeastern Louisiana. Flooding of the salt mine began when a collapse sinkhole developed in the lake, coinciding with the sinking of a drilling rig. The lake drained into the hole, and landslides and mudflows developed along the perimeter of the sinkhole (Autin, 2002). No injuries occurred in the disaster, but the resulting damages totaled hundreds of millions of dollars, and the salt mine was permanently closed. As the legal and political battles at Jefferson Island subsided, the safety of mining operations at the Belle Isle salt mine came into question. Subsidence over the mine area led to questions about the structural integrity of the salt dome. Horizontal stress on the mine shaft near the salt contacts overlying late Pleistocene deposits caused mine shaft deterioration, broad ground subsidence over the mine area, and groundwater leakage into the mine. Continued difficulty with mine operations and increased risk of catastrophic collapse were considered as distinct possibilities. In 1985, a controlled flooding of the Belle Isle salt mine was completed as part of a safe closure plan (Autin, 2002). Another flooding incident associated with a mining explosion on August 24, 1961, in a hydrocarbon well at Nagyhegyes in eastern Hungary (Sütö, 2010) resulted in a crater and pond about $8 \mathrm{~km}^{2}$ in area and over $9 \mathrm{~m}$ deep.

Engineering geology and geomorphology may be helpful approaches in reducing environmental impacts and hazards in vulnerable locations. Finding the best sites through prospecting minimizes the potential footprint. Gongyu and Wanfang (1999) described intercepting streams and diverting river channels as a means to reduce the groundwater inflow to nearby coal mines. They presented a case study from Enkou Mine in China, where grouting screens to cut off karst groundwater flows, cementing stream channels, and alteration of stream paths were adopted and proved effective in reducing the groundwater inflow to the mines that had been flooded via induced karst features. Some companies are using sustainable mining practices. Geomorphic analysis plays an important role in sustainability and developing solutions to potential problems in mined settings, including managing landscape disturbance, protecting surface and groundwater, minimizing impacts from blasting, and controlling dust and noise (Langer et al., 2003). Community involvement and awareness of best management practices of sustainability and biodiversity can be adopted by the mining industry, societal priorities influence how the mineral industry acts, and the consuming public makes choices about products obtained from mining (Shields et al., 2006).

\subsubsection{Geomorphology and Mine Reclamation}

Geomorphic approaches and understandings are increasingly being used in designing plans for reclamation of mined lands. Hundreds of new landforms can be created in a very short time through the removal of huge quantities of overburden, resulting in high-relief landforms, which then have the potential for failure and associated environmental and hydrologic problems (Nyssen and Vermeersch, 2010). Use of geomorphic principles to understand mined land reclamation is relatively recent, as early efforts at land reclamation commonly created a distinctive landform suite (Haigh, 1978). Reclamation generally does not reestablish the original topography, but aims to reduce off-site impacts and promote soil formation and the establishment of self-sustaining functional ecosystems through the management and control of geomorphic processes (e.g., Martín-Duque et al., 2010). Sometimes, there are many more water bodies on the landscape than had been originally present. For example, the lignite mining in Central Germany described earlier that altered a $600 \mathrm{~km}^{2}$ landscape, resulting in a larger number of lakes (Hildmann and Wonsche, 1996). Reclamation has emphasized the reestablishment of cultivation with an important focus on the protection of aquatic systems downslope through creating landscapes that decrease runoff and reduce sediments and contaminants. Thus, there is currently more emphasis on understanding the watershed as a restoration unit (Nicolau, 2003). Because this area of research is relatively new, much learning is occurring from case studies.

One of the challenges of reclamation in the future in some areas will be restoring the form and function of streams at or near mined areas. In streams such as the Bowie River in Mississippi (Mossa, 2006) and Amite River in Louisiana (Mossa and McLean, 1997), where large volumes of sand have been removed and sold for construction, recreating the original form is not possible. A different scenario exists in Florida, where the phosphate-mining industry has removed several meters of overburden and the headwater streams that traverse the surface. The first goal in this case is to reclaim the land, and the industry has developed a process to accelerate the rate of drying of clay-rich landscapes (Figure 13). These Florida streams were destroyed before they could be studied. Assuming that the land is successfully reclaimed, they will be recreated using geomorphic data from reference reaches in minimally disturbed areas throughout peninsular Florida (Blanton et al., 2010). Although there is geomorphic knowledge behind the restoration, and this is helpful in designing the form of new streams, re-establishing stream function is a bigger challenge and will take several more decades to monitor and improve, if funding and resources allow. In areas with metal contamination, such as Soda Butte Creek in Yellowstone National Park, contamination from a tailings dam failure has lasted several decades and is likely to continue for many more, such that the biota or function of the stream has a long road to recovery (Marcus et al., 2001). 


\subsubsection{Conclusion}

Mining is a human activity with a long history. It has a wide and diverse range of direct and indirect geomorphic effects by creating unique types of excavated and accumulated landforms and landscapes that are more vulnerable to geomorphic hazards than most similar unmined landscapes. The geomorphic effects vary not only with the scale of the operation but also with the nature of the materials and the landscape being mined, the type of mining operation involved (e.g., underground vs. surface), the history of mining in the region, and remedial practices, if any.

Mining landscapes covered more than a half million hectares worldwide in 1990 (Young, 1992) and are responsible for more sediment production than paved road construction, house construction, and agriculture, and all combined produce more sediment than by natural processes (Hooke, 1994, 1999). Removal of vegetation and surface sediments, blasting, creation of stock piles and gangue, and increasing slope gradients make landscapes more vulnerable to failures, erosion, floods, subsidence, and other geomorphic hazards and have been the subject of a number of studies. In spite of negative environmental consequences, mining will continue because of the extreme economic importance of the resources obtained. In addition, the impacts of mining may be much less than nearby land uses. For example, Langer et al. (2004) noted that the land disturbed to build a community or a highway is about 100 times greater than the land disturbed to provide the aggregate for those purposes.

In any case, mining should be employed with careful consideration of mediating environmental impacts and for reclamation of land after changes due to mining.

Reclamation is still a nascent discipline, and much conscientious applied work, combined with monitoring, will result in better functioning landscapes that are less susceptible to hazards in time. We have much still to learn from the study of mining landscapes, with potential applications in landscape evolution, models of geomorphic hazards, and Quaternary geology and geomorphology. Given a growing global population, and expanding mineral resource demands, these impacts will grow and geomorphic study of these landscapes will become increasingly important.

\section{References}

Adriaanse, L.A., Coosen, J., 1991. Beach and dune nourishment and environmental aspects. Coastal Engineering 16, 129-146.

Agricola, Georgii (a.k.a. Georg Pawer). 1530. Bermannus, sive de re metallica dialogus.

Agricola, Georgii, 1546. De ortu \& causis subterraneorum, Lib. V; De natura eorum quae effluunt ex terra, Lib. IIII; De natura fossilium, Lib. X; De ueteribus \& nouis metallic, Lib. II; Bermannus, siue De re metallica Dialogus, Lib. I. Interpretatio Germanica uocum rei metallicae. Addito indice fScundissimo. Froben and Nicolaus Episcopius, Basel: (Hieronymus).

Agricola, Georgius, 1556. De Re Metallica. Translated by Hoover, H.C., Hoover,

L.H., 1912; London: The Mining Magazine. (translated version online).

Alexander, D., 1986. Northern Italian dam failure and mudflow, July 1985. Disasters $10,3-7$.

Arnell, N., 2002. Hydrology and Global Environmental Change. Prentice Hall, London.
Arnold, L.R., Langer, W.H., Paschke, S.S., 2003. Analytic and Numerical Simulation of the Steady-State Hydrologic Effects of Mining Aggregate in Hypothetical Sand-and-Gravel and Fractured Crystalline-Rock Aquifers. USGS Water Resources Investigations Report 02-4267, 56 pp.

Autin, W.J., 2002. Landscape evolution of the Five Islands of south Louisiana: scientific policy and salt dome utilization and management. Geomorphology 47, $227-244$

Barras, J., Beville, S., Britsch, D., et al., 2003. Historical and Projected Coastal Louisiana Land Changes: 1978-2050. USGS Open File Report 03-334, 39 pp.

Bell, F.G.L., Donnelly, J., Genske, D.D., Ojeda, J., 2005. Unusual cases of mining subsidence from Great Britain, Germany and Colombia. Environmental Geology 47, 620-631.

Blanton, K., Mossa, J., Kiefer, J., Wise, W.R., 2010. Bankfull indicators in small blackwater streams in peninsular Florida: reliability and relations with hydrology. Southeastern Geographer 50, 422-444.

Bolen, W.E., 2002. Sand and gravel (construction): US Geological Survey Mineral Commodity Summaries, 140-141.

Bowie, Jr. A.J., 1885. A Practical Treatise on Hydraulic Mining in California: With Description of the Use and Construction of Ditches, Flumes, Wrought Iron Pipes, and Dam. D. Van Nostrand, New York (Available on Google Books).

Brim-Box, J., Mossa, J., 1999. Sediments, land use, and freshwater mussels: prospects and problems. Journal of the North American Benthologists Society 18, 99-117.

Britsch, L.D., Dunbar, J.B., 1993. Land-loss rates: Louisiana coastal plain. Journal of Coastal Research 9, 324-338.

Brown, A.V., Lyttle, M.M., Brown, K.B., 1998. Impacts of gravel mining on gravel bed streams. Transactions of the American Fisheries Society 127 979-994.

Brown, H.S., Kasperson, R.E., Raymond, S.S., 1990. Trace pollutants. In: Turner, II B.L., Clark, W.C., Kates, R.W., Richards, J.F., Mathews, J.T., Meyer, W.B. (Eds.), The Earth as Transformed by Human Action: Global and Regional Changes in the Biosphere over the Past 300 Years. Cambridge University Press, Cambridge, pp. 437-454.

Bull, W.B., Scott, K.M., 1974. Impact of mining gravel from urban stream beds in the Southwestern United States. Geology 2, 171-174.

Byrnes, M.R., Hammer, R.M., Thibault, T.D., Snyder, D.B., 2004. Effects of sand mining on physical processes and biological communities offshore New Jersey, USA. Journal of Coastal Research 20, 25-43.

Chilingar, G.V., Endres, B., 2005. Environmental hazards posed by the Los Angeles Basin urban oilfields: an historical perspective of lessons learned. Environmental Geology 47, 302-317.

Cho, D., 2006. Challenges to sustainable development of marine sand in Korea. Ocean and Coastal Management 49, 1-21.

Clark, J.R., 1996. Coastal Zone Management Handbook. CRC Press, Boca Raton, $\mathrm{FL}, 720 \mathrm{pp}$.

Cooke, R.U., Doornkamp, J.C., 1990. Geomorphology in Environmental Management: A New Introduction, Second ed. Clarendon Press, Oxford, 410 pp. Craddock, P.T., 1995. Early Metal Mining and Production. Edinburgh University Press, Edinburgh, $363 \mathrm{pp}$.

Dahl, T.E., 1990. Wetlands losses in the United States: 1780 s to 1980 s. US Department of the Interior, Fish and Wildlife Service, Washington, DC.

Dávid, L., 2010. Quarrying and other minerals. In: Szabó, J., Dávid, L., Lóczy, D. (Eds.), Anthropogenic Geomorphology: A Guide to Man-Made Landforms. Springer, Dordrecht, The Netherlands, pp. 113-130 (Chapter 9).

Davis, J., Bird, J., Finlayson, B., Scott, R., 2000. The management of gravel extraction in alluvial rivers: a case study from the Avon River, southeastern Australia. Physical Geography 21, 133-154.

Demek, J. (Ed.), 1972. Manual of Detailed Geomorphological Mapping. Academia, Prague.

Femmer, S.R., 2002. Instream Gravel Mining and Related Issues in Southern Missouri. US Geological Survey, Reston, VA.

Gaillot, S., Piégay, H., 1999. Impact of gravel- mining on stream channel and coastal sediment supply, example of the Calvi Bay in Corsica (France). Journal of Coastal Research 15, 774-788.

Getschow, G., Petzinger, T., 1984. Louisiana marshlands, laced with oil canals, are rapidly vanishing. Wall Street Journal, October 24, p. 1.

Ghosh, A.K., Reddy, K.R.G., Prasad, C.D., 2006. Mechanisation of beach placer mining above water table: some preliminary considerations. Journal of Mines, Metals and Fuels 54, 64-71.

Gilbert, G.K., 1917. Hydraulic-Mining Débris in the Sierra Nevada. US Geological Survey Professional Paper 105.

Gongyu, L., Wanfang, Z., 1999. Sinkholes in karst mining areas in China and some methods of prevention. Engineering Geology 52, 45-50. 
Government Accounting Office (GA0), 2009. Surface Coal Mining: Characteristics of Mining in Mountainous Areas of Kentucky and West Virginia. GA0-10-21. Washington, DC.

Graf, W.L., 1994. Plutonium and the Rio Grande: Environmental Change and Contamination in the Nuclear Age. Oxford University Press, New York.

Greenland, P., 2001. Hydraulic Mining in California: A Tarnished Legacy. Arthur H. Clark Co., Spokane, WA, $320 \mathrm{pp}$.

Gregory, C.E., 1980. A Concise History of Mining. Pergamon Press, New York; Oxford, $259 \mathrm{pp}$

Griffith, J.S., Andrews, D.A., 1981. Effects of a small suction dredge on fishes and aquatic invertebrates in Idaho streams. North American Journal of Fisheries Management 1, 21-28.

Guerrero, F.A., Lozano, M., Rueda-Cantuche, J.M., 2008. Spain's greatest and most recent mine disaster. Disasters 32, 19-40.

Haigh, M.J., 1978. The Evolution of Slopes on Artificial Landforms, Blaenavon, UK. University of Chicago Press, Chicago, IL, 307 pp.

Hanson, H., Brampton, A., Capobianco, M., et al., 2002. Beach nourishment projects, practices, and objectives - a European overview. Coastal Engineering 47, 81-111.

Harden, C.P., 1993. Upland erosion and sediment yield in a large Andean drainage basin. Physical Geography 14, 254-271.

Harden, C.P., 2006. Human impacts on headwater fluvial systems in the northern and central Andes Geomorphology. Proceedings of the 37th Binghamton Geomorphology Symposium on The Human Role in Changing Fluvial Systems, vol. 79, pp. 249-263.

Hartmann, H.L., Mutmansky, J.M., 2002. Introductory Mining Engineering, Second ed. Wiley, Hoboken, NJ, 584 pp.

Harvey, B.C., Lisle, T.E., 1998. Effects of suction dredging on streams: a review and an evaluation strategy. Fisheries 23, 8-17.

Harvey, M.D., Schumm, S.A., 1987. Response of DryCreek, California, to land use change, gravel mining and dam closure. Proceedings of the Corvallis Symposium on Erosion and Sedimentation in the Pacific Rim, August 1987. International Association of Hydrological Sciences Publication 165, pp. 451-460.

Hay, I., 1985. Some environmental implications of alluvial gold dredging on the Grey River, Westland. New Zealand Geographer 41, 8-14.

Heiss, A.G., Oeggl, K., 2008. Analysis of the fuel wood used in Late Bronze Age and Early Iron Age copper mining sites of the Schwaz and Brixlegg area (Tyrol, Austria). Vegetation History and Archaeobotany 17, 211-221.

Herbich, J.B., 1981. Dredging equipment and the effects of dredging on the environment. In: Gayer, R.A. (Ed.), Marine Environmental Pollution 2: Dumping and Mining. Elsevier, Amsterdam, pp. 227-240.

Hildmann, E., Wonsche, M., 1996. Lignite mining and its after-effects on the central German landscape. Water, Air, and Soil Pollution 91, 79-87.

Holland and Knight Law Firm, 1980. The Phosphate Lands Controversy: A Perspective. Holland \& Knight, Tampa, FL, 279 pp.

Holliday, J.S., 1981. The World Rushed In: The California Gold Rush Experience. Simon and Schuster, New York, $559 \mathrm{pp}$.

Holliday, J.S., 1999. Rush for Riches: Gold Fever and the Making of California. University of California Press.

Hooke, R., 1994. On the efficacy of humans as geomorphic agents. GSA Today 4(217), 224-225.

Hooke, R., 1999. Spatial distribution of human geomorphic activity in the United States: comparison with rivers. Earth Surface Processes and Landforms 24, $687-692$

Hooke, R., 2000. On the history of humans as geomorphic agents. Geology 28, $843-846$.

Hoyer Millar, C.C., 1892. Florida, South Carolina, and Canadian Phosphates: Giving a Complete Account of Their Occurrence, Methods and Cost of Production, Quantities Raised, and Commercial Importance. Eden Fisher \& Co., London, England, $223 \mathrm{pp}$.

Hudson-Edwards, K.A., Macklin, M.G., Jamieson, H.E., Brewer, P.A., Coulthard, T.J., Howard, A.J., Turner, J.N., 2003. The impact of tailings dam spills and clean-up operations on sediment and water quality in river systems: the Ríos Agrio-Guadiamar, Aznalcóllar, Spain. Applied Geochemistry 18, 221-239.

Hudson-Edwards, K.A., Macklin, M.G., Miller, J.R., Lechler, P.J., 2001. Sources, distribution and storage of heavy metals in the Río Pilcomayo, Bolivia. Journa of Geochemical Exploration 72, 229-250.

Hughes, S., 1994. The hushing leats at Cwmystwyth. Bulletin of The Peak District Mines Historical Society 12(3), 48-53.

Hull, C.D., Burnett, W.C., 1996. Radiochemistry of Florida phosphogypsum. Journal of Environmental Radioactivity 32, 213-238.
Hunerlach, M.P., Alpers, C.N., Marvin-DiPasquale, M., Taylor, H.E., DeWild, J.F., 2004. Geochemistry of Mercury and Other Trace Elements in Fluvial Tailings Upstream of Daguerre Point Dam, Yuba River, California. US Geological Survey Scientific Investigations Report 2004-5165, August 2001, 66 pp.

James, L.A., 1989. Sustained storage and transport of hydraulic mining sediment in the Bear River, California. Annals of the Association of American Geographers $79,570-592$

James, L.A., 1991. Incision and morphological evolution of a channel recovering from hydraulic mining sedimentation. Geological Society of America Bulletin 103, 723-726.

James, L.A., Singer, M.B., Ghoshal, S., Megison, M., 2009. Sedimentation in the lower Yuba and Feather Rivers, California: Iong-term effects of contrasting river-management strategies. In: James, L.A., Rathburn, S.L., Whittecar, G.R. (Eds.), Management and Restoration of Fluvial Systems with Broad Historical Changes and Human Impacts: Geological Society of America Special, 451. http://dx.doi.org/10.1130/2009.2451(04).

Johnes, M., 2000. Aberfan and the management of trauma. Disasters 24, 1-17.

Johnson, D.L., Lewis, L.A., 1995. Land Degradation: Creation and Destruction. Blackwell, Oxford, UK.

Katpatal, Y.B., Patil, S.A., 2010. Spatial analysis on impacts of mining activities leading to flood disaster in the Erai watershed, India. Journal of Flood Risk Management 3, 80-87.

Kelley, R.L., 1959. Gold vs. Grain, The Hydraulic Mining Controversy in California's Sacramento Valley. Arthur H. Clark Company.

Kesler, S.E., 1994. Mineral Resources, Economics and the Environment. Macmillan College Publishing, New York, $391 \mathrm{pp}$.

Knox, J.C., 1987. Historical valley floor sedimentation in the Upper Mississippi Valley. Annals of the Association of American Geographers 77, 224-244.

Kondolf, G.M., 1994. Geomorphic and environmental effects of instream gravel mining. Landscape and Urban Planning 28, 225-243.

Kondolf, G.M., 1997. Hungry water: effects of dams and gravel mining on river channels. Environmental Management 21, 533-551.

Lagasse, P.F., 1986. River response to dredging. Journal of the Waterway, Port, Coastal and Ocean Engineering Division, American Society of Civil Engineers $112,1-14$.

Lagasse, P.F., Winkley, B.R., Simons, D.B., 1980. Impact of gravel mining on river system stability. Journal of the Waterway, Port, Coastal and Ocean Engineering Division, American Society of Civil Engineers 106, 389-404.

Langer, W.H., 1988. Natural aggregates of the conterminous United States. US Geological Survey Bulletin 1594. US Geological Survey, Denver, C0.

Langer W.H., Drew, L.J., Sachs, J.S., 2004. Aggregate and the environment. American Geological Institute Environmental Awareness Series 8, American Geological Institute, Alexandria, VA.

Langer, W.H., Šolar, S.V., Shields, D.J., Giusti, C., 2003. Sustainability indicators for aggregates. In: Agioutantis, Z. (Ed.), Proceedings of the International Conference on Sustainable Development Indicators in the Minerals Industries, Milos Conference Center, Athens, Greece, pp. 251-257.

deLeeuw., J., Shankman, D., Wu, G., et al., 2010. Strategic assessment of the magnitude and impacts of sand mining in Poyang Lake, China. Regional Environmental Change 10, 95-102.

Lecce, S.A., Pavlowsky, R.T., 1997. Storage of mining-related zinc in floodplain sediments, Blue River, Wisconsin. Physical Geography 18, 424-439.

Leenaers, H., 1989. The transport of heavy metals during flood events in the polluted River Geul (TheNetherlands). Hydrological Processes 3, 325-338.

Lewin, J., Bradley, S.B., Macklin, M.G., 1983. Historical valley alluviation in midWales. Geological Journal 18, 331-350.

Lewin, J., Davies, B.E., Wolfenden, P.J., 1977. Interactions between channel change and historic mining sediments. In: Gregory, K.J. (Ed.), River Channel Changes. Wiley, Chichester, pp. 353-367.

Macklin, M.G., 1996. Fluxes and storage of sediment-associated heavy metals in floodplain systems: assessment and river basin management issues at a time of rapid environmental change. In: Anderson, M.G., Walling, D.E., Bates, P.D. (Eds.), Floodplain Processes. John Wiley \& Sons, Chichester, pp. $441-460$.

Macklin, M.G., Brewer, P.A., Hudson-Edwards, K.A., et al., 2006. A geomorphological-geochemicalapproach to river basin management in miningaffected rivers. In: James, L.A., Marcus, W.A. (Eds.), The Human Role in Changing Fluvial Systems. Proceedings of the 37th Binghamton Symposium in Geomorphology. Elsevier, Amsterdam, pp. 423-447.

Magoon, O.T., Lent., L.K., 2005. The costs of sand mining: when beaches disappear, who benefits, who pays? California Coast and Ocean 21, 3-8.

Mancini, F., Stecchi, F., Zanni, M., Gabbianelli, G., 2009. Monitoring ground subsidence induced by salt mining in the city of Tuzla (Bosnia and 
Herzegovina). Environmental Geology (Special Issue: Current Perspectives on the Environmental Impacts and Hazards in Karst) 58, 381-389.

Marcus, W.A., Meyer, G.A., Nimmo, D.R., 2001. Geomorphic control of persistent mine impacts in a Yellowstone Park stream and implications for the recovery of fluvial systems. Geology 29, 355-358.

Marston, R.A., Bravard, J., Green, T., 2003. Impacts of reforestation and gravel mining on the Malnant River, Haute-Savoie, French Alps. Geomorphology 55, 65-74.

Martín-Duque, J.F., Sanz, M.A., Bodoque, J.M., Lucía, A., Martín-Moreno, C., 2010. Restoring earth surface processes through landform design. A 13-year monitoring of a geomorphic reclamation model for quarries on slopes. Earth Surface Processes and Landforms 35, 531-548.

Masalu, D.C.P., 2002. Coastal erosion and its social and environmental aspects in Tanzania: a case study in illegal sand mining. Coastal Management 30 , 347-359.

May, P.R., 1970. Origins of Hydraulic Mining in California. Holmes Book Company, Oakland, CA.

McLachlan, A., 1996. Physical factors in benthic ecology: effects of changing sand particle size on beach fauna. Marine Ecology Progress Series 131, 205-217.

Meador, M., Layher, A.O., 1998. Instream sand and gravel mining: environmental issues and regulatory process in the United States. Fisheries 23, 6-13.

Menzie, D., Tse, P., Fenton, M., Jorgenson, J., van Oss, H. 2004. China's Growing Appetite for Minerals, US Geological Survey, Open-File Report 2004-1374.

Mensah, J.V., 1997. Causes and effects of coastal sand mining in Ghana. Singapore Journal of Tropical Geography 18, 69-88.

Miller, J.R., 1997. The role of fluvial geomorphic processes in the dispersal of heavy metals from mine sites. Journal of Geochemical Exploration 58, 101-118.

Morton, R.A., 2003. An Overview of Coastal Land Loss: With Emphasis on the Southeastern United States. USGS Open File Report 03-337.

Morton, R.A., Tiling, G., Ferina, N.F., 2003. Causes of hot-spot wetland loss in the Mississippi delta plain. Environmental Geosciences 10, 71-80.

Mossa, J., 1995. Sand and gravel mining in the Amite River floodplain. Guidebook of Geological Excursions, Proceedings of the New Orleans Meeting, Geological Society of America, pp. 235-260.

Mossa, J., 2006. Quantifying channel planform change. Papers of the Applied Geography Conference 29, 65-70

Mossa, J., Marks, S.R., 2011. Pit avulsions and planform change on a mined river floodplain: Tangipahoa River, Louisiana, USA. Physical Geography 32, 512-532. http://dx.doi.org/10.2747/0272-3646.32.6.512.

Mossa, J., Mc Lean, M., 1997. Channelplanform and land cover changes on a mined river floodplain: Amite River, Louisiana, USA. Applied Geography 17 , 43-54.

Mulaba-Bafubiandi, A.F., Mukendi-Ngalula, D., Waanders, F.B., 2002. Imenite mineral's recovery from beach sand tailings. Hyperfine Interactions 139-140, 485-494.

Newport, B.D., Moyer, J.E., 1974. State-of-the-art: sand and gravel industry. US Environmental Protection Agency Technical Series Report 660/2-74-0066. Washington, DC.

Nicolau, J.-M., 2003. Trends in relief design and construction in opencast mining reclamation. Land Degradation and Development 14, 215-226.

Nir, D., 1983. Man, A Geomorphological Agent. Keter Publishing House, Boston.

Norman, D.K., Cederholm, C.J., Lingley, Jr. W.S., 1998. Flood plains, salmon habitat, and sand and gravel mining. Washington Geology 26, 3-20.

Nyssen, J., Vermeersch, D., 2010. Slope aspect affects geomorphic dynamics of coal mining spoil heaps in Belgium. Geomorphology 123, 109-121.

Palmer, M.A., Bernhardt, E.S., Schlesinger, W.H., et al., 2010. Science and regulation: mountaintop mining consequences. Science 327, 148-149.

Panigrahi, K.N., 2005. Beach sand mining and its separation in 0scom, Orissa (India). Proceedings of Heavy Minerals Conference 2005, pp. 23-26.

Paul, R.W., 1947. California Gold: The Beginning of Mining in the Far West. University of Nebraska Press, Lincoln, $380 \mathrm{pp}$.

Pirkle, F.L., Pirkle, W.A., Pirkle, E.C., Pirkle, D.L., 2005 Heavy mineral milling in the Atlantic coastal plain of Florida and Georgia and the chemical and physical characteristics of the deposits. Proceedings of Heavy Minerals Conference 2005, pp. 7-18.

PliniusSecundus (Pliny the Elder). c. AD 77-79. NaturalisHistoria (Natural History).

Poland, J.F., Davis, G.H., 1969. Land subsidence due to withdrawal of fluids. In: Varnes, D.J., Kiersch, G. (Eds.), Reviews in Engineering Geology. Geological Society of America, Boulder, C0, vol. 2, pp. 187-269.

Pousa, J., Tosi, L., Kruse, E., et al., 2007. Coastal processes and environmental hazards: The Buenos Aires (Argentina) and Venetian (Italy) littorals. Environmental Geology 51, 1307-1316.
Rico, M., Benito, G., Díez-Herrero, A., 2008a. Floods from tailings dam failures. Journal of Hazardous Materials 154, 79-87.

Rico, M., Benito, G., Salgueiro, A.R., Dízz-Herrero, A., Pereira, H.G., 2008b. Reported tailings dam failures: a review of the European incidents in the worldwide context. Journal of Hazardous Materials 152, 846-852.

Rule, J., 1998. A risky business: death, injury and religion in Cornish mining $\mathrm{C.}$ 1780-1870. In: Knapp, A.B., Pigott, V.C., Herbert, E.W. (Eds.), Social Approaches to An Industrial Past: The Archaeology and Anthropology of Mining. Routledge, London, pp. 155-173, 328

Sandecki, M., 1989. Aggregate mining in river systems. California Geologist 42, 88-94.

Saville, A., 2008. Flint extraction and processing from secondary flint deposits in the north-east of Scotland in the Neolithic Period. In: Allard, P., Bostyn, F., Giligny, F., Lech., J. (Eds.), Flint Mining in Prehistoric Europe: Interpreting the Archaeological Records. BAR International Series 1891. Archaeopress, Oxford, UK, pp. 1-10.

Saylor, K.L., 2008. Land Cover Trends: Central Appalachians. US Department of the Interior, US Geological Survey, Washington, DC.

Schrotenboer, B.R., Arbogast, A.F., 2010. Locating alternative sand sources for Michigan's foundry industry: a geographical approach. Applied Geography 30, 697-719.

Scott, K.M., 1973. Scour and Fill in Tujunga Wash - A Fanhead Valley in Urban Southern California - 1969. US Geological Survey Professional Paper 732-B, US Government Printing Office, Denver.

Sear, D.A., Archer, D., 1998. Effects of gravel extraction on stability of gravel-bed rivers: the WoolerWater, Northumberland, UK. In: Klingman, P.C., Beschta, R.L., Komar, P.D., Bradley, J.B. (Eds.), Gravel-Bed Rivers in the Environment. Water Resources Pubs., LLC, Highlands Ranch, CO, USA, pp. $415-432$

Sgambat, J.P., Labella, E.A., Roebuck, S. 1980. Effects of underground coal mining on groundwater in the eastern United States. EPA Interagency Energy/ Environmental Research and Development Program Report, EPA-600/7-80-120, $182 \mathrm{pp}$.

Shields, D., Šolar, S.V., Langer, W., 2006. Sustainable Development and Industrial Minerals. Industrial Minerals and Rocks, Seventh ed. Society of Mining, Metallurgy and Exploration, Denver, C0, 133-142.

Smith, D.A., 1987. Mining America: The Industry and the Environment, 1800-1980. University of Kansas Press, Laurence, KS, $210 \mathrm{pp}$.

Somer, W.L., Hassler, T.J., 1992. Effects of suction-dredge gold mining on benthic invertebrates in a northern California stream. North American Journal of Fisheries Management 12, 244-252.

Strabo. c. 25 BC Geographica. Various translations and online versions exist.

Surian, N., Rinaldi, M., Pellegrini, L., et al., 2009. Channel adjustments in northern and central Italy over the last 200 years. In: James, L.A., Rathburn, S.L., Whittecar, G.R. (Eds.), Management and Restoration of Fluvial Systems with Broad Historical Changes and Human Impacts: Geological Society of America Special, 451. http://dx.doi.org/10.1130/2009.2451(04).

Sütő", L., 2010. Extraction of fossil fuels. In: Szabó, J., Dávid, L., Lóczy, D. (Eds.), Anthropogenic Geomorphology: A Guide to Man-Made Landforms. Springer, Dordrecht, The Netherlands, pp. 131-154 (Chapter 10).

Tepordei, V.V., 2002. Stone (crushed). US Geological Survey Mineral Commodity Summaries, . 156-157.

Theron, A.K., Schoonees, J.S., Huizinga, P., Phelps, D.T., 2003. Beach diamond mining design at the rocky Namaqualand coast. Proceedings of the Conference on Coastal Structures, pp. 949-961.

Thornton, E., Sallenger, A., Sesto, J., Egley, L., McGee, T., Parsons, R., 2006. Sand mining impacts on long-term dune erosion in southern Monterey Bay. Marine Geology 229, 45-58.

Turner, R.E., Lee, J.M., Neill, C., 1994. Backfilling canals to restore wetlands: empirical results in coastal Louisiana. Wetlands Ecology and Management 3, 63-78

Uribelarrea, D., Pérez-González, A., Benito, G., 2003. Channel changes in the Jarama and Tagus rivers (Central Spain) over the last 250 years. Quaternary Science Reviews 22, 2209-2221.

US Army Corps of Engineers-Mobile District, 2000. Ecosystem Restoration Report and Environmental Assessment of Big Escambia Creek. Section 206, Aquatic Ecosystem Restoration Project near Flomaton, AL and Century, FL, US Army Corps of Engineers, Mobile District.

US Bureau of Mines, 1996. Dictionary of Mining, Mineral, and Related Terms. (CD-ROM).

US Environmental Protection Agency Mountaintop Mining/Valley Fills in Appalachia: Final Programmatic Environmental Impact Statement. 2005-10-25. 
Valverde, H.R., Trembanis, C., Pilkey, O.H., 1999. Summary of beach nourishment episodes on the US East Coast barrier islands. Journal of Coastal Research 15, 1100-1118.

Vitruvius, M.ca. 15 B.C. De architectura (On architecture); Translated, 1914, as "Ten Books on Architecture"; Morgan, M.H.(translator).

Wampler, P.J., Schnitzer, E.F., Cramer, D., Lidstone, C., 2006. A meander cutoff into a gravel extraction pond, Clackamas River, Oregon. Preprint 06-041 Presented at the Society Mining Engineers Annual Meeting, St. Louis, MO, USA.

Wellmer, F.W., Becker-Platen, J.D., 2002. Sustainable development and exploitation of mineral and energy resources: a review. International Journal of Earth Sciences $91,723-745$

Young, J.E., 1992. Mining the Earth. In: Brown, L.R., et al. (Eds.), State of the World - 1992, (cited by Johnson and Lewis, 1995).

Young, R., Griffith, A., 2009. Documenting the global impacts of beach sand mining. Geophysical Research Abstracts, vol. 11, EGU 2009-11593. EGU General Assembly 2009.

\section{Relevant Websites}

http://coastalcare.org//wp-content/pdt/egu-2009.pdf Coastal Care.

http://www.farlang.com/gemstones/agricola-metallica/ Farlang.

http://www1.fipr.state.fl.us/PhosphatePrimer

Florida Institute for Phosphate Research, 2011. http://www.maden.hacettepe.edu.tr/dmmrt/index.html Hacettepe University, Department of Mining Engineering.

http://www.kennecott.com/visitors-center/ Kennecott Utah Copper.

http://www.simetric.co.uk/si_materials.htm

Mass, Weight, Density or Specific Gravity of Bulk Materials, 2011.

http://www.mii.org

Minerals Information Institute, 2011.

http://earthobservatory.nasa.gov/I0TD/view.phpid=8144

National Aeronautical and Space Administration.

http://www.strabo.ca/editions.html

Strabo the Geographer, maintained by Sarah Pothecary.

http://www.epa.gov/region03/mtntop/index.htm

U.S. Environmental Protection Agency.

http://landcovertrends.usgs.gov/east/ec069Report.html

U.S. Geological Survey.

http://pubs.usgs.gov/of/2004/1374/2004-1374.pdf

U.S. Geological Survey.

http://purl.access.gpo.gov/GP0/LPS100301

U.S. Geological Survey.

http://pubs.usgs.gov/ds/2005/139/

U.S. Geological Survey.

http://www.bukisa.com/articles/218700_worlds-largest-open-pit-mines

World's Largest Open Pit Mines, 2009

\section{Biographical Sketch}

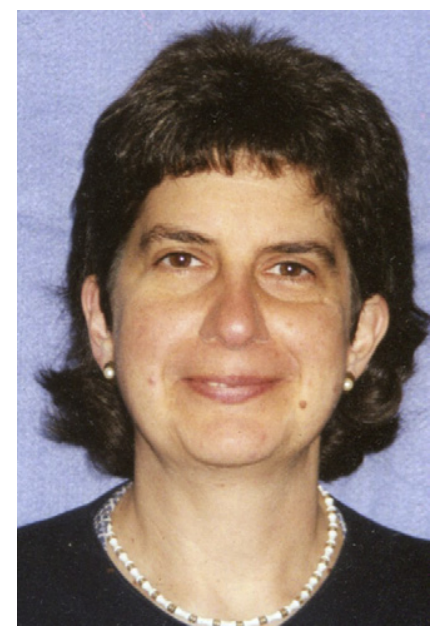

Joann Mossa is Associate Professor and Undergraduate Coordinator in the Department of Geography at the University of Florida, Gainesville, FL. She holds affiliate appointments in Geological Sciences, Hydrologic Sciences, and the School of Natural Resources and Environment. She received undergraduate degrees in geography and mathematics from Rutgers University, and a masters and a Ph.D. in geography from Louisiana State University, Baton Rouge. Her research in geomorphology involves rivers, coasts, and soils. Her current work examines the role of floods and varied historical human impacts in causing or accelerating river channel changes, sometimes applied toward river restoration. She currently serves on the editorial board of Physical Geography and the Southeastern Geographer. In the past, she served as chair of the Geomorphology Specialty Group and the Coastal and Marine Specialty Group of the Association of American Geographers and President of the Florida Society of Geographers. She was also visiting faculty scientist at the Waterways Experiment Station, US Army Corps of Engineers in Vicksburg, MS, and a research associate at the Louisiana Geological Survey.

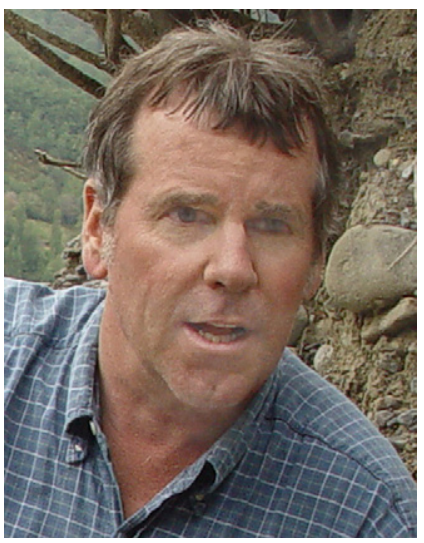

Allan James is a professor in the Department of Geography at the University of South Carolina, Columbia, SC. He received an undergraduate degree in geography at the University of California, Berkeley, master's degrees in water resources management and geography at the University of Wisconsin, Madison, and a PhD in geography and geology at the University of Wisconsin, Madison. His primary research interests are in river and watershed science, fluvial geomorphology, and linking human impacts in river systems to historical sedimentation and flood hydrology. He is also engaged in research on human-environment interactions, water resources, and hydrogeomorphic applications of geographic information (GI) science. He has allied interests in geomorphometry and remote sensing applied to historical change detection, especially to fluvial systems and gullies, and mapping geomorphic evidence of former glaciations in the Sierra Nevada, CA. He has served as chair of the Geomorphology Specialty Group of the Association of American Geographers, panelist to the Geomorphology and Quaternary Science Division of the Geological Society of America, founding editor of the GSG_AAG web page, and national councilor to the AAG. 